\title{
RACE DISCRIMINATION IN HOUSING
}

THE Report of the President's Committee on Civil Rights has once again called public attention to the discrepancy between American aspiration and accomplishment in race relations. ${ }^{1}$ Housing clearly illustrates the national failure to treat individuals on the basis of individual merit rather than racial myth. In the construction of the twelve million homes required in the next decade to meet America's needs, ${ }^{2}$ either present patterns of racial segregation will be perpetuated, or racially integrated housing will be encouraged. Since the course of the law will be a major factor in determining which of these alternative housing patterns develops in the future, it seems imperative to reconsider the basic constitutional issue: to what extent do the Fifth and Fourteenth Amendments prohibit racial discrimination in private or in publicly aided housing? Legal reevaluation is made all the more pressing by the restrictive covenant cases (awaiting decision on the merits for the first time in the Supreme Court), and by the first case involving discrimination in a redevelopment project. The ingredients of a fresh appraisal are a realistic picture of Negro housing in America and a review and critique of the decisions involving discrimination by government or private home owners.

\section{Negro Housing in America}

The condition of Negro-occupied residences best illustrates the problem of racial discrimination in housing. All available data demonstrate that $\mathrm{Ne}$ gro homes are substandard, overcrowded, segregated, generally inferior-in every section of the country, and on every income level. ${ }^{3}$

1. To Secure These Rigits: The Report of the President's Commitree on Civil Rrghts (1947). Hereafter cited as Crv. RTS. REP.

2. ". . . [I]n order to put the housing plant of the United States in reasonable shape there should be built in 10 years about 12,000,000 houses." Statement by Senator Taft, Hearings before Committee on Banking and Currency on S. 287, S. 866, S. 701, and S. s01-4, 80th Cong., 1st Sess. 3 (1947). See also Nat. Ass'N of Housing Officinls, Housing for the United States After the War 7 (1944); Rosensian, A Million Homes a Year (1945); Blandford, Wanted 12 Million New Houses, 34 Nat. Munic. Rev. 376 (1945);Mr. Wyatt's Shortage, Fortune, April, 1946, p. 105.

3. The statistical data to be presented are corroborated by sociological descriptions of Negro housing. "Nothing is so obvious about the Negroes' level of living as the fact that most of them suffer from poor housing conditions." MYrDal, AN AMErican Dilesma 376 (1944). See also, e.g., Drake and Cayton, Black Metropolis (1945); Woorter, Negro Problems in Cities (1928).

The intensive study of Negro youth prepared for the American Youth Commission in 1940 attested to the inferiority of Negro housing. The summary statement was: "Negro homes, all in all, are dreary dwellings, on neglected streets without pavements, littered by accumulated wastes, in the oldest sections of the city." REID, IN A Minor KEY 25 (1940). Reports from each section of the country described poor housing. ATWOod, WYATT, DAvis and Walker, Thus Be their Destiny 2, 12-3, 43, 68-70 (1941) (Milton, Pa., Greensboro, N.C. and Galesburg, Ill.); Davis, Gardner aNd Gardner, DeEp Soutu 22, 50-4, 387-8, 468-70 (1941) (urban and rural); Frazier, Negro Youth at the Crossways,6-18, 200, 
room, as compared to $12 \%$ of the white homes; in Detroit the percentages were $26 \%$ Negro and $12 \%$ white; in Norfolk, $27 \%$ and $11 \% 0^{\circ}$ Certain areas of the Black Belt in Chicago have a population density of 90,000 per square mile, while neighboring white apartments have a density of 20,000.7 Baltimore Negroes, $20 \%$ of the city's population, are jammed into $2 \%$ of the homes. ${ }^{8}$

In addition, Negro homes are cut.off from the rest of the community. Official and unofficial mapping of the location of Negro residences reveals clearly defined segregated areas. ${ }^{9}$ An FHA study concluded that the intensity of segregation increases directly with the number and proportion of the non-white population. ${ }^{10}$ In Chicago, for example, it has been estimated that over $90 \%$ of the Negroes live in areas predominantly Negro. ${ }^{11}$ Segregation distinguishes Negro housing from slum housing in general.

Since the segregation of Negroes is "indiscriminate," 12 all social and economic segments of the race are trapped behind ghetto walls. The Negro who strives to live by the social and ethical standards of the majority must reside, nonetheless, in the neighborhood of poverty, filth and vice. As a consequence of this and other forms of enforced segregation, full assimilation of prevailing cultural values is not achieved..$^{13}$ The distortion of social values

6. Id. at 193. In 1940, "While less than eight per cent of the dwelling units occupicd by urban whites were overcrowded, almost 25 per cent of the units occupied by urban Negroes were overcrowded. Although the nonwhite urban population between 1930 and 1940 increased 7.7 per cent, as compared to 7.2 per cent for whites, the supply of housing available for non-whites increased 12.7 per cent as compared to 16.6 per cent for whites." Weaver, supra note 4 , at 95.

7. Drake and Cayton, Black Metropolis 204 (1945).

8. TENendaud, Why MEN Hate 335 (1947). If the national population density were the same as that of a certain Harlem block, the entire U.S. population would require only half the area of New York City. Ibid. In the Los Angeles "little Tokyo" area which housed 7,500 before the war, 30,000 Negroes lived during the war. NAT. URDAN LEAGUE, RACraL Problems in Housing, Bull. No. 2 at 16 (3d ed. 1945). In Detroit, while the average unit housed 3.8, "To house all Negro families at an average of 4.0 persons per occupied dwelling unit would require 53,000 dwellings, or an increase of 19,000 over the number of dwellings occupied by Negroes in 1940: However, 8,000 homes occupied by Negroes in 1940 were physically sub-standard. Since many of the remaining homes occupied by Negroes are aged frame structures, badly overcrowded, an equal number may be expected to become obsolete over the next ten years." Detroit City Planning Commission, The People of Detroit 19 (1946). On a country-wide average, the median number of rooms per dwelling unit in 1940 was 4.9 for white and 3.5 for Negro. Robinson, Relationship Between Conditions of Dwellings and Rentals, by Race, 22 J. LAND \& PUB. UT. Econ. 296, 300 (1946).

9. See Woofter, Negro Problems in Cities 40-67 (1928); FHA, op. cit. supra note 4 , at $45,47,69-70$.

10. FHA, op. cit. supra note 4, at 68.

11. Drake and Cayton, Black Metropolis 174 (1945).

12. President's Conference 26; Drake and Cayton, Black Metropolis 206 (1945).

13. Segregation is the "pathological feature of the Negro community." It "produces an artificial situation in which inferior standards of excellence and efficiency are set up. Since the Negro is not required to compete in the larger world and to assume its responsibilities and suffer its penalties, he does not have an opportunity to mature." FraziER, 
in the Negro neighborhood is manifest in higher crime rates, and in relatively greater expense to the community in required police, fire and health services. $^{14}$ In Chicago's Black Belt, for example, the rate of juvenile delinquency is eight times, and the death rate almost twice that in the rest of the city.15 Moreover, through preoccupation with segregation, potentially creative energy is wasted by both the majority and minority races. This process of waste is most dramatically illustrated in the race riot. Inferior, segregated housing is one of the primary causes of strained race relations which periodically culminate in race warfare. ${ }^{16}$

When the Negro seeks housing outside his segregated area, he is thwarted

Negro Youth at the Crossways 290 (1940). Consciousnees of discrimination affects Negroes' attitudes towards important social issues, so that even war is loolsed at from a race rather than from any broader point of view. Id. at sxii. ". . . Many young Negross have never experienced the American dream. They have never inown a society composed of respectable, law-abiding, industrious, self-reliant families whose ambition has been rewarded by good houses, electric refrigerators, and an improved social status." SUTEERL.AND, op. cit. supra note 3, at 15. See also Cooper, The Frustrations of Bcing a Lember of a Afinority Group, 29 MeNTAL HygreNe 189 (1945). Additional insight is provided by a numbar of novels: Petro, The Street (1946); Wright, Blace Boy (1945); Moon, Darker Brotaer (1913); Wright, NatrVe Son (1940).

14. "At least three types of social pathology have been observed to have a high and inescapable correlation with the character of Negro residence areas. These are: (1) A high rate of delinquency, (2) A high rate of mortality, and (3) A distorted standard of living." Presment's Conference 52. Rates of "dependency, family decertion and illegitimacy .. . [are] high in those areas that were characterized by physical decay and lack of organized community life." Frazier, The Negro Family in tae United States 373-4 (1939). A Chicago housing conference "listed among the 'ghetto conditions' high siclness and death rates; a heavy relief load during the Depression; inadequate recreational facilities; lacl: of building repairs; neglect of garbage disposal and street cleaning; overcrowded schools; high rates of crime and juvenile delinquency; and rough treatment by the police." Drake aND Cayton, Blace Mietropolis 202 (1945). Segregation can also frustrate the operation of a city plan: "Badly in need of a medical center, express highways, parlss and other deferred civic improvements, Detroit must wait indefinitely for them. The land they will occupy now houses hundreds of Negro families who can't be evicted beeause there's no place for them to go." Velie, Housing: Delroil's Time Bomb, Colliers, Nov. 23, 1946, p. 15, col. 1.

15. Gertz, American Ghetros 8 (1947). Such data generally show an improvement when decent housing is provided. See GRAY, Housisg ANd Cirizensaip 125-6 (1946); Johnson, Into The Main Streasr 223 (1947); Moon, Tae Higg Cost of Prejudice 37 (1947). In a Cincinnati housing project for Negroes, built in the twenties with private funds, the rate of arrest was 1 per 215 inhabitants annually; the rate in the city generally was 1 par 15 for whites and 1 per $71 / 2$ for Negroes. Presidenr's Cosferestce 105.

16. LEE, RACE Ruor $60,89,93,119$ (1943) analyzes the Detroit riots. Even in the absence of riots, violence is part of the race housing picture. E.g., "From May 1944 through July 1916-a period of twenty-seven months - 59 attacks were made on Negro residences in Chicago. About half were arson-bombings. There vere 22 cases of stoning, three shootings, three house-wreckings, two stench-bombings. Three persons were killed and many

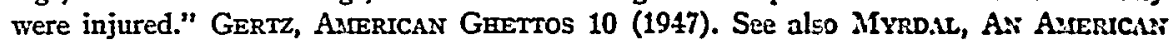
Dilemara 624 (1941); President's Conference 46; Martin, The Trulh About Sojoumer Truth, 49 Crrsis 112 (1942); BROWN, WHY RACE RroTs (1944).

"Anyone who has investigated the problem of group tensions has always ended up 
by discrimination enforced informally or in the courts. The public housing available to lower income groups includes many segregated projects. ${ }^{17}$ In redevelopment housing projects, financed by private investment companies and accommodating lower middle-class tenants, the redevelopment companies' privilege of discrimination has been upheld in an initial court test. ${ }^{18}$ Since these projects, authorized in the past few years in twenty states, ${ }^{19}$ may soon become the most significant source of new dwelling units, ${ }^{20}$ the decision as to whether they shall be segregated or mixed may be crucial for the es* tablishment of future racial patterns in American housing. In seeking to buy or build a home of his own, the Negro is faced with the restrictive covenant, apparently the most widely used technique for enforcing discrimination in private housing. In large cities such as Chicago and Los Angeles racial covenants have almost completely cut off any possibility of expanding the Negro housing area. ${ }^{21}$ Most covenants are imposed by the original subdividers, ${ }^{22}$ or reflect the participation of realtors' organizations in their draft-

with the belief that nothing radical can be achieved until the walls of segregated, hemmed-in, ghetto living have been destroyed." Tenenbaus, Why Men Hate 333 (1947). There appears to be unanimity among writers on race relations that housing is the crucial issue. For typical statements, see DraKe and Cayton, Black Metropolis 114 (1945); Moton, Winat The Negro Thinks 117 (1929); The Negro Problesi: Housing a Basic Factor (reprint by American Council on Race Relations of war time columns by Barry Bishop in the Dallas Morning News).

17. See pp. 436 infra.

18. Dorsey v. Stuyvesant Town Corp., 118 N.Y.L.J. 163 (Sup. Ct. July 29, 1947). See pp. 437-44 infra.

19. For a comparative analysis of state urban redevelopment legislation see Hearings before Committee on Banking and Currency on S. 1592, 79th Cong., 1st Sess. 485-524 (1945); Nat. Ass' of Housing Officials, Summary of the 1945 Housing Year 9-14 (1946).

20. Metropolitan Life Insurance Company, for example, a leading investor in redevelopment housing, has over 100,000 tenants in its projects. Statement of Mr. Gcorge Gove, Vice-President of Metropolitan Life, Hearings before Commillee on Banking and Currency on S. 287, 866, 701, and 801-4, 80th Cong., 1st Sess. 336-42 (1947). Because of incentives in the form of tax subsidy and use of public authority, redevelopment housing is bound to increase. See notes 55, 57, 60,61 infra.

21. ". . . Many areas, particularly large cities in the North and West, such as Chicago, Cleveland, Washington, D.C., and Los Angeles, are widely affected. The amount of land covered by racial restrictions in Chicago has been estimated at 80 per cent. Students of the subject state that virtually all new subdivisions are blanketed by these covenants." Crv. RTS. REP. 68.

In Chicago, estimates of land coverage by covenants have gone as high as $85 \%$ and it has been stated that in the entire city there are "only 500 to 600 lots . . . known to be available in any but the worse slum areas upon which housing can be built for Negro occupancy without the use of eminent domain." NAT. URBAN LEAGUE, op. cil. supra note 8 , at 16. In Los Angeles, a recent "fever of cases" attests to the extent of covenants, GERTZ, AMERICAN GHetros 6 (1947).

22. See, e.g., Burkhardt v. Lofton, 63 Cal. App.2d 230, 146 P.2d 720 (1944); Lettcall v. Ellis, 122 Cal. App. 584, 10 P.2d 496 (1932); Janss Investment Co. v, Walden, 196 Cal. 753, 239 Pac. 34 (1925); Los Angeles Investment Co. v. Gary, 181 Cal. 680, 186 Pac. 596 (1919); Title Guarantee \& Trust Co. v. Garrott, 42 Cal. App. 152, 183 Pac. 470 (1919); Chandler v. Ziegler, 88 Colo. 1, 291 Pac. 822 (1930); Edwards v. West Woodbridge Theater 
ing, recordation, enforcement and general administration. ${ }^{23}$ These organizations prey on existing fears that loss of property values, social status and neighborhood friends will follow when a Negro moves into a community. ${ }^{28}$

Attempts to justify this pervasive pattern of segregation in terms of Negro traits follow three recurring types of argument, none of which seems tenable. Thus, it is often alleged that the Negro is an irresponsible tenant, notwithstanding the excellent rent-paying ${ }^{25}$ and maintenance ${ }^{s s}$ records of Negroes

Co., 55 F.2d 524 (App. D.C. 1931); Cornish v. O'Donoghue, 30 F.2d 983 (App. D.C. 1929); McCurdy v. Standard Realty Corp., 295 Ky. 586, 175 S.IW.2d 28 (1943); Queensborough Land Co. v. Cazeaux, 136 La. 724, 67 So. 641 (1915); MIRSA v. Reynolds, 317 Mlich. 632, 27 N.W.2d 40 (1947); Northwest Civic Ass'n v. Sheldon, 317 Mich. 416, 27 N.W.2d 36 (1947); Parmalee v. Morris, 218 Mich. 625, 188 N.W. 330 (1922); Phillips v. Wearn, 226 N.C. 290, 37 S.E.2d 895 (1946); Vernon v. Reynolds Realty Co., 226 N.C. 58, 36 S.E.2d 710 (1946); Ridgway v. Cockburn, 163 Misc. 511, 296 N.Y. Supp. 936 (Sup. Ct. 1937); Bulen v. Rice, 11 Ohio L. Abs. 175 (Ohio App. 1931); Crump v. Perryman, 193 S.IW.2d 233 (Civ. App. Tex. 1946). In Detroit, approximately $90 \%$ of race covenants have been imposed by original subdividers. Black, Patterns of Restrictive Covenants (unpublished thesis, Wayne University, 1948). A study of subdivisions opened in the past 10 years in Queens, Nacsau and Southern Westchester Counties in New York shows that $83 \%$ of the larger (75 homes and over) projects are restricted from the start. Architectural Forum, Oct., 1947, p. 16. Sie Dean, Only Caucasian: A Study of Race Corenants, 23 J. Land \& Pub. Ut. Ecorr. 428 (1947).

23. See, e.g., Russell v. Wallace, 30 F.2d 981 (App. D.C. 1929); Meade v. Dennistone, 173 Md. 295, 196 Atl. 330 (1938); Kraemer v. Shelley, 198 S.W.2d 679 (Mo. 1946), cert. granted, 67 Sup. Ct. 1751 (1947); Thornhill v. Herdt, 130 S.IW.2d 175 (St. Louis Ct. App. 1939); Pickel v. McCawley, 329 Mo. 166, 44 S.IW.2d 857 (1931).

"The most stubborn resistance in America to Negro advance is offered by realtors and landholders." Conrad, Jim Crow Asirgica 234 (1947). See also Mixrdal, Ax Auerucas Dilemara 624 (1944); Nat. URban League, op. cit. sutpra note 8, at 16-7; Jonisos:, Isito The Mian Streass 220 (1947).

See various publications of National Association of Real Estate Boards which has filed a brief amicus supporting covenants in the pending litigation. Local organizations, also, have issued publications, e.g., Chicago Federation of Neigrborrood Associntio:ss, RestrucTIVE Covenants (1944). "The agreements which have been used in . . Chicago . . on the South Side have been prepared by the Chicago Real Estate Board and have been approved by the Chicago Title And Trust Company." Letter of Albert H. Veeder, Attorney, to Oscar H. Boenicke, May 15, 1936. One Chicago association has boasted that the 104 blocks it covers is $100 \%$ covenanted against Negroes. Weaver, Race Restriclite Housing Cocenomts, 20 J. LAND \& PUB. Ut. ECoN. 183, 188 (1941). In St. Louis, approximately 85\% of all covenants were drawn in the same form by the Real Estate Exchange. Note, 3 Nat. Bar J. $50,51(1945)$.

24. See, e.g., Johnson, Patterns of Negro Segregation 11-2 (1943); Weaver, supra note 4 , at 96 . The latter author suggests that occupancy standards be substituted for racial restrictive covenants in new developments as a means of conserving property values. Id. at 102; Planning for More Flexible Land Use, 23 J. LaNd \& PUB. UT. Ecos. 29, 41 (1947).

25. "For 155 projects in 59 cities having two or more FPHA-aided projects, at least one of which is occupied by Negro tenants, the following results are reported: Collection losses do not exceed one percent of the total operating incomes for a total of 142 of these projects, 72 of which are occupied by Negroes and 70 by white or other tenants. Five of the 13 projects showing rental losses in excess of one per cent are tenanted by Negrows and 8 are tenanted by whites or others. The collection loss records between the two racial groups do not differ more than one per cent in $\mathbf{5 1}$ of the $\mathbf{5 9}$ cities and the records are identical in 
who have been given the opportunity to live in modern housing developments. Also, on the assumption that each man gets the full housing value he can pay for, it is frequently argued that Negroes cannot obtain better housing because of inability to pay rather than because of discrimination. But Negro families get less for their housing dollar than white families on the same income level; ${ }^{27}$ and, indeed, the relative inferiority actually encreases as the rental value increases. ${ }^{28}$ Finally, it is contended that segregation is inevitable because Negroes and whites cannot live together, but this assertion is refuted by a substantial body of evidence on interracial living in federal housing projects. ${ }^{29}$ In 325 federal projects providing for occupancy by both Negro and white tenants, the policy ranged from setting

34." Weaver, Race Restrictive Housing Covenants, 20 J. LAND \& PUB. UT. EcoN. 183, 189 (1944).

26. For data on Negro maintenance, see President's Conference 249-57; Jounson, To Stem This TIDE 61 (1943); Weaver, supra note 25, at 191 n.24.

27. "The rent of Negro dwellings is a plain indication of the exploitation of Negro neighborhoods. These rents are excessive whether they are measured by the kind of house and equipment, by the relation of rents paid by Negroes and those paid by white pcople for similar quarters, by the steady increase in rents, by the relation of rent to the value of the property, or by the proportion which rent forms of the family budget." Woortek, Negro Problems in Cities 121 (1928) with supporting data on preceding pages. "Negro residents of the Chicago 'Black Belt' pay as much per cubic foot per room as that paid by wealthy residents for equivalent space of the Lakeside Drive." Cayton, Negro Housing in Action, Social Action, April 5, 1940, p. 18. See also Frazier, The Negro Family in the United States 458 (1939); Myrdal, AN AMerichN Dilemala 625 (1944); President's Conference 26,58 ; and note 28 infra.

28. For the following data based on the 1940 Housing Census, see Robinson, supra note 8 , at 297 :

\begin{tabular}{|c|c|c|c|c|c|c|c|c|c|}
\hline \multirow{3}{*}{$\begin{array}{c}\text { Monthly Renlat } \\
\text { Volute (Est.) }\end{array}$} & \multicolumn{9}{|c|}{ Percenlage of Sub-standard Unils in Each Renlal Bracket } \\
\hline & \multicolumn{3}{|c|}{ Total } & \multicolumn{3}{|c|}{$\begin{array}{l}16 \text { Northern and } \\
\text { Western Cilties }\end{array}$} & \multicolumn{3}{|c|}{26 Southern Distriels } \\
\hline & While & $\begin{array}{l}\text { Non- } \\
\text { white }\end{array}$ & $\left(\begin{array}{c}\text { Ratio } \\
\text { Non-white } \\
\text { to while }\end{array}\right)$ & While & $\begin{array}{l}\text { Non- } \\
\text { white }\end{array}$ & $\left(\begin{array}{c}\text { Ratio } \\
\text { Non-while } \\
\text { to while }\end{array}\right)$ & Whitc & $\begin{array}{l}\text { Non: } \\
\text { while }\end{array}$ & $\left.\begin{array}{c}\text { Rallo } \\
\text { Non-tohile } \\
\text { to while }\end{array}\right)$ \\
\hline $\begin{array}{l}\text { Under \$5 } \\
\$ 5-\$ 9 \\
\$ 10-\$ 14 \\
\$ 15-\$ 19 \\
\$ 20-\$ 24 \\
\$ 25-\$ 29\end{array}$ & $\begin{array}{l}90.2 \\
87.7 \\
69.4 \\
42.1 \\
25.0 \\
14.4\end{array}$ & $\begin{array}{l}97.6 \\
94.7 \\
79.4 \\
55.3 \\
43.8 \\
31.0\end{array}$ & $\begin{array}{l}1.1 \\
1.1 \\
1.1 \\
1.3 \\
1.8 \\
2.2\end{array}$ & $\begin{array}{l}76.5 \\
87.3 \\
71.7 \\
43.1 \\
24.2 \\
13.6\end{array}$ & $\begin{array}{l}95.1 \\
93.9 \\
81.1 \\
56.9 \\
44.2 \\
30.0\end{array}$ & $\begin{array}{l}1.2 \\
1.1 \\
1.1 \\
1.3 \\
1.8 \\
2.2\end{array}$ & $\begin{array}{l}94.2 \\
88.0 \\
66.1 \\
39.1 \\
27.2 \\
16.9\end{array}$ & $\begin{array}{l}97.8 \\
94.9 \\
78.5 \\
53.1 \\
42.8 \\
34.8\end{array}$ & $\begin{array}{l}1.0 \\
1.1 \\
1.2 \\
1.3 \\
1.6 \\
2.1\end{array}$ \\
\hline $\begin{array}{l}\$ 30-\$ 39 \\
\$ 40-\$ 49 \\
\$ 50-\$ 59 \\
\$ 60-\$ 74 \\
\$ 75-\$ 99 \\
\$ 100 \text { and over }\end{array}$ & $\begin{array}{l}7.7 \\
4.0 \\
3.2 \\
2.8 \\
2.7 \\
2.8\end{array}$ & $\begin{array}{l}20.9 \\
13.5 \\
10.9 \\
9.1 \\
10.7 \\
13.4\end{array}$ & $\begin{array}{l}2.7 \\
3.4 \\
3.4 \\
3.3 \\
3.9 \\
4.8\end{array}$ & $\begin{array}{l}7.1 \\
3.7 \\
3.1 \\
2.8 \\
2.9 \\
3.2\end{array}$ & $\begin{array}{l}20.5 \\
13.6 \\
11.5 \\
9.6 \\
11.9 \\
14.9\end{array}$ & $\begin{array}{l}2.9 \\
3.7 \\
3.7 \\
3.4 \\
4.1 \\
4.7\end{array}$ & $\begin{array}{r}10.1 \\
5.3 \\
3.7 \\
2.7 \\
2.1 \\
1.8\end{array}$ & $\begin{array}{r}22.8 \\
13.2 \\
9.0 \\
7.8 \\
7.2 \\
7.5\end{array}$ & $\begin{array}{l}2.3 \\
2.5 \\
2.4 \\
2.9 \\
3.4 \\
4.2\end{array}$ \\
\hline \multicolumn{10}{|c|}{ Total No. of Unils Reparting: } \\
\hline $\begin{array}{l}\text { White: } \\
\text { Non-white }\end{array}$ & & & $\begin{array}{r}6,365,845 \\
850,063\end{array}$ & & & $\begin{array}{r}4,772,155 \\
427,648\end{array}$ & & & $\begin{array}{r}1,503,690 \\
422,415\end{array}$ \\
\hline
\end{tabular}

29. USHA, Experdence in Public Housing Projects Jointly Occupied dy Negro, White, and Other Tenants (1944 Annual Conference of Racial Relations Advisers); Abradrs, Race Bias in Housing 20-5 (1947). For a report of similar experiences in cmployment see Weaver, Negro Labor cc.XI, XII (1946). 
aside specific areas for a particular race, to adherence to a principle of no segregation. Harmonious race relations were most thoroughly achieved in those projects which maintained a policy of fully integrating the races, the residents accepting the new neighborhood standard of no segregation in much the same way as they had previously accepted segregation in the communities from which they came. ${ }^{30}$ The extent of the mutual respect engendered by interracial living was demonstrated during the Detroit race riots, when Negroes and whites who had lived together in the same section of the city showed no disposition to join in the general violence. 31

An inquiry into this pattern of discrimination should be an integral part of any thorough attack on the legal problems involved in racial segregation. Without an awareness of the implications of each decision in relation to this sociological background, analysis by the courts of the doctrinal issues would appear to be barren indeed.

\section{Legal Status of Discrimination in Housing}

The central constitutional problem involved in racial segregation is to distinguish private action from public action. The Fourteenth Amendment provides that: "No State shall . . . deprive any person of life, liberty, or property, without due process of law; nor deny to any person within its jurisdiction the equal protection of the laws." 32 Although the Fifth Amendment states without qualification, "No person shall . . . be deprived of life, liberty, or property without due process of law," 33 traditional court interpretation has limited the application of this protection to action by the federal government..$^{34}$ These Amendments have foreclosed, at least as a constitutional issue, discriminatory action by public authority, state or federal. But the question remains: what is "public"? The difficulty in thinking of

30. "Where Negroes are integrated with whites into self-contained communities without segregation, reach daily contact with their co-tenants, are given the same privileges and share the same responsibilities, initial latent tensions tend to subside, distinctions become reconciled, cooperation ensues and an environment is created in which intersacial harmony will be effected." ABRAsrs, op. cit. supra note 29, at 22. For a case cxample of how a policy of race integration succeeded see Hovde, Negro Housing in Piltsbargls, 16 OPPORTUNITY 356 (1938).

The meaningfulness of this body of evidence has been discounted recently in a contrasting of public and private projects: "Moreover, in the former case, the tenant, beesuse of his economic condition, has little or no freedom of choice respecting living accommodations. In the latter case, the type of Jesirable tenant has great freedom of choice." Affidavit of Gove, Vice-President of Metropolitan Life Insurance Co., July 9, 1947. But see Civ. Rrs. RER. 70 for a contrary view.

31. "No Negroes and whites who lived close together as neighbors showed any tendency" to fight each other." LEE, RACE Rrot 17 (1943).

32. U.S. Const. Arrend. XIV, \&1 (emphasis added).

33. U.S. CONST. AMIEND. V (emphasis added).

34. Barron v. Baltimore, 7 Pet. 243 (U.S. 1833), is the leading case, and Adamson v. California, 67 Sup. Ct. 1672 (1947), the most recent major discussion of the issues currently being posed. 
any private rights independent of recognition and protection by government, indicates that "public" and "private" are not separate compartments but titles for opposing ends of a continuous spectrum. ${ }^{35}$ Courts have been faced with the problem of isolating unconstitutional public discrimination from permissible private discrimination in three recurring types of fact situation: action by public officials, by urban redevelopers, and by private agreement.

\section{Segregation by Public Officials}

That the legal standard of "separate but equal" facilities is inapplicable in the field of housing and that racial segregation implemented by legislative action comes within the prohibition of the Fourteenth Amendment was determined by the Supreme Court in the leading case of Buchanan $v$. Warley. ${ }^{30}$ Before the Court was a Louisville ordinance providing that neither white nor colored could purchase or rent property in any block in which the majority of the residents were of the opposite race. Plaintiff, a white man, was seeking specific performance of an executory contract for the sale of real estate from a Negro purchaser who resisted enforcement on the ground that the ordinance made the transfer of clear title impossible. In rendering a decree for the plaintiff, the Court held that the ordinance violated the Fourteenth Amendment by depriving the parties of their right to buy and sell property and hence was no bar to enforcement of the contract. The Court rejected the "separate but equal" argument employed to sustain the validity of segregation legislation in other fields, such as public transportation and

35. "As a matter of fact, the courts have never been able to establish any fundamental distinction between 'public' and 'private' agencies. They all alike live, move, and have their being in the law. The distinction is largely, or wholly, a matter of custom. That which has generally been considered to be 'public' is 'public,' and that which has generally been considered to be 'private' is 'private' . . . , and what was once considered to be 'private' may later, when conditions change, become 'public'." Barnett, What is "Stale" Action Under the Fourteenth, Fifteenth, and Nineteenth Amendments of the Constihution?, 24 ORE. L. REv. 227, 229-30 (1945). For the suggestion that the Fifth and Fourteenth Amendments may apply to the action of private groups, see note $119 \mathrm{infra}$.

36. 245 U.S. 60 (1917) reversing $165 \mathrm{Ky} .559,177$ S.W. 472 (1915).

Many southern cities had adopted ordinances patterned after the original 1911 Baltimore ordinance preserving, in effect, the block by block racial status quo. In litigation involving the constitutionality of these ordinances, three states, besides Kentucky, held such enactments to be a valid exercise of the police power. Harden v. Atlanta, $147 \mathrm{Ga} .248$, 93 S.E. 401 (1917); but cf. Carey v. Atlanta, 143 Ga. 192, 84 S.E. 456 (1915) (such ordinances are unconstitutional); State v. Gurry, 121 Md. 534, 88 Atl. 546 (1913) (invalid only because retroactive and thus taking property without due process); Hopkins v. Richmond, $117 \mathrm{Va} .692,86 \mathrm{~S} . \mathrm{E} .139$ (1915). One state court in a very strong opinion had invalidated a race ordinance as beyond a municipality's power. State v. Darnell, 166 N.C. 300, 81 S.E. 338 (1914). For discussion of these cases see Mangum, The Legal Sratus of Tite Negro 139-45 (1940); Hott, Constitutionality of Municipal Zoning and Segregation Ordinances, 33 W.VA. L.Q. 332, 341-9 (1927).

An even more discriminatory ordinance, which required Chinese to move to a specified area of San Francisco, was invalidated in the early case of In re Lee Sing, 43 Fed. 359 (N.D. Cal. 1890). 
educational facilities, on the theory that since land is a unique commodity it is impossible to provide "equal" housing sites. 37 Therefore, the Constitution required that the opportunity to buy and sell land must be freely available to all on a non-discriminatory basis. Finally, it was said that the ordinance could not be justified as a reasonable exercise of the police power. ${ }^{23}$

Two subsequent decisions have extended the anti-segregation doctrine of Buchanan v. Warley. In Harmon v. Tyler, ${ }^{39}$ the state statute and city ordinance required the consent of a majority of the residents of a particular block or area for the purchase or occupancy of any home by a member of the other race. The possibility of a transfer of property, it was argued, corrected the defect in the Buchanan case, where the express terms of the ordinance made any transfer impossible. If no sale actually took place, it would be not because of the statute but because of the voluntary failure of private citizens to consent. Although the state courts found merit in this distinction, ${ }^{40}$ the Supreme Court perceived no difference and unanimously reversed per curiam on the basis of Buchanan $v$. Warley. Thus, segregation ordinances were unconstitutional despite provision for the voluntary action of private individuals.

In Richmond $v$. Deans, ${ }^{41}$ the ordinance provided that no one might purchase or lease property in any block in which the majority of the residents were of such race that there could be no marriage between them and the potential occupant. It was hoped that segregation in housing might be ac-

37. In distinguishing Plessy v. Ferguson, 163 U.S. 537 (1896) (carriers), and Berea College v. Kentucky, 211 U.S. 45 (1908) (education), the Court quoted with approval from Carey v. Atlanta, 143 Ga. 192, 201, 84 S.E. 456, 459 (1915): "The most that was done was to require him [the Negro] as a member of a class to conform with reasenable rules in regard to the separation of the races. In none of them was he denied the right to use, control, or dispose of his property, as in this case." Buchanan v. Warley, 245 U.S. 60, 80 (1917).

38. "That there exists a serious and difficult problem arising from a feeling of race hostility which the law is powerless to control, and to which it must give a measure of consideration, may be freely admitted. But its solution cannot be promoted by depriving citizens of their constitutional rights and privileges." Id. at 80-1.

There has been some criticism of the decision on the ground that the Court did not properly weigh the reasonableness of the legislative action as a means of achieving a possible public benefit. Martin, Segregation of Residences of Negrows, 32 MIIcr. L. REv. 721, 726-31 (1934); Hott, supra note 36, at 348-9; cf. Note, 29 KY. L. J. 213 (1941). Prior to the decision, proponents of the ordinances centered on the police power rationale. Benson, Segregation Ordinances, 1 VA. L. REG. (N.S.) 330 (1915); Hunting, The Constitutionality of Race Distinctions and the Baltinore Negro Segregation Ordinance, 11 Coz. L. REv. 24 (1911); Minor, Constitutionality of Segregation Ordinances, 18 VA. L. REg. 501 (1912).

39. 273 U.S. 668 (1927).

40. 158 La. 439, 104 So. 200 (1925), 36 YALE L. J. 274 (1926). The Louisiana Court relied on Plessy v. Ferguson, 163 U.S. 537 (1896), mentioning the Buchonan case only as an afterthought and insisting that it had not overruled the Plessy decision, and that in any case sufficient distinction existed in the fact that sale was not now forbidden. Id. at 454-8, 104 So. at 205-7. A concurring opinion called the Buclanan decision "a long step baclswards in the march of civilization" which ought to be overruled. Id. at 462, 104 So. at 208.

41. 281 U.S. 704 (1930), affirming 37 F.2d 712 (C.C.A. 4th 1930). 
cepted as merely a reasonable method of enforcing the miscegenation laws which had been upheld as a valid exercise of the police power. ${ }^{\Delta 2}$ However, the Supreme Court, in another unanimous per curiam decision citing Btichanan $v$. Warley, invalidated the ordinance. Thus, segregation in housing was not to be excused by being tied to an approved public policy. ${ }^{43}$

Despite this clearly established constitutional prohibition, racial segregation exists through government action in public housing today. There are many more federally-aided locally-administered projects restricted to one race than apen to both. ${ }^{44}$ Many more Negroes live in segregated than in racially integrated projects. ${ }^{45}$ However, the Public Housing Administration has pioneered in establishing projects which eschew race discrimination, and the Negro has more than his population-ratio share of public housing. ${ }^{46}$

In the case of the Federal Housing Authority which underwrites loans for building or remodelling private homes, discrimination against Negroes has apparently been practiced through informal pressures on banks and other private lenders. ${ }^{47}$ The FHA Underwriting Manual contained a provision

42. Pace v. Alabama, 106 U.S. 583 (1882). See Mangum, op. cit. supra note 36, at 236 et seq.

43. Three state decisions, two since the Deans case and the other a year before it, attest to the tenacity of the forces favoring segregation, and also to the adherence of state courts to the Supreme Court ordinance cases, since all resulted in invalidation of the ordinances. Clinard v. Winston-Salem, 217 N.C. 119, 6 S.E.2d 867 (1940), 29 KY. L. J. 213 (1941) (ordinance passed in 1930 not litigated until race boundaries were modified in 1939); Allen v. Oklahoma City, 175 Okl. 421, 52 P.2d 1054 (1936) (with Negroes moving into white residential areas, the Governor declared martial law because violence was "imminent," and directed the city to enact the ordinance); Dallas v. Liberty Annex Corp., 280 S.W. 1067 (Civ. App. Tex. 1926), aff'd, 19 S.W.2d 845 (Civ. App. Tex. 1929), 8 TEx. L. REv. 298 (1930) (ordinance provided criminal penalties for violation of segregation agreement signed by certain whites and Negroes). Compare Jackson v. State, 132 Md. 311, 103 Atl. 910 (1918) with State v. Gurry, 121 Md. 534, 88 Atl. 228 (1913). Compare Irvine v. Clifton Forge, 124 Va. 781, 97 S.E. 310 (1918) with Hopkins v. Richmond, 117 Va. 692, 86 S.E. 139 (1915).

Cf. Oyama v. California, 16 U.S.L. WeEK 4108 (U.S. Jan. 20, 1948).

While Buckanan v. Warley has thus far been consistently followed, the "equal but separate" standard in non-housing felds is under attack. See Crv. RTs. REP. 79-87; Report of President's Commission on Higher Education, N.Y. Times, Dec. 16, 1947, p. 44, cols. 2-3; Note, Segregation in Public Schools-A Violation of "Equal Protection of the Laws," 56 YALE L. J. 1059 (1947). See Sipuel v. Bd. of Regents, 16 U.S.L. WeEK 4079 (U. S. Jan. 12, 1948),

44. As of June 30,1941 , of 380 projects, 327 were for a single race, 194 for whites only, 133 for Negroes only. Sterner, The Negro's Share 320 (1943). As of Dec. 31, 1943, the FPHA controlled or supervised 705,066 dwelling units. 2 NHA ANN. REP. 97a (1943). Of these; 27,562 , a small minority, provided for occupancy by both whites and Negroes. USHA, op. cit. supra note 29, at 4. For a brief account of wartime official attempts to establish segregation, see JoHnson, To Stes This Tide 49-59 (1943).

45. Of 92,476 dwelling units occupied by Negro tenants as of Jan. 31,1944 , almost 65,000 provided for total occupancy by Negroes. Id. at 5 . In pre-war projects under $20 \%$ of units occupied by Negroes were in "jointly occupied projects," but during the war, $46 \%$. McGraw and Horne, The House I Live In, 24 OpPoRTUNiTY 122, 126 (1946).

46. STERNER, op. cit. supra note 44, at 316-20. Negroes occupied $15.5 \%$ of public war housing units just before V-J day. McGraw and Horne, supra note 45 , at 125.

47. See STERnER, op. cil. supra note 44, at 314-6; Dean, supra note 22, at 430-1. 
which seemingly encouraged race covenants. While this provision has recently been revised, the altered phraseology appears inadequate to require any change in policy. ${ }^{48}$ It has been suggested that FHA operations have resulted not only in the maintenance but even in the extension of race restrictive covenants. ${ }^{49}$ Thus segregation in housing is apparently being accomplished through administrative action despite Supreme Court decisions prohibiting residential segregation through government action.

\section{Segregation by Urban Redevelopers}

Urban redevelopment housing, for which neither the label "public" nor "private" is wholly appropriate, presents a unique legal problem. A major purpose of the redevelopment laws is to insure that the housing which replaces the slum buildings of central blighted areas be constructed as far as possible by private enterprise. ${ }^{50}$ To this end the laws provide for a partnership of public authority and private capital, and define the duties and benefits of each of the partners. ${ }^{51}$ Illustrative of the race issue in this new type of housing is the New York litigation over Stuyvesant Town, the first largescale postwar housing development ready for occupancy.

48. Compare "Generally, a high rating should be given . . . where effective restrictive covenants are recorded against the entire tract, since these provide the surest protection against undesirable encroachment and inharmonious use. To be most effective, deed restrictions should be imposed upon all land in the immediate environment of the subject location. . . . Recommended restrictions should include procisions for lic folloscing. . . . Prohibition of the occupancy of properties except by the race for adlich they ore interded." FHA, UNDERWRITING MANOAL, par. 980 (1938) (emphasis added); will "If the occupancy of the neighborhood is changing from one user group to another, or if the areas adjacent to the immediate neighborhoods are occupied by a group dissimilar to the typical occupants of the subject neighborhood, or a change in occupancy is imminent or probable, any degree of risk is reflected in the rating. It is to be noted that additional risk is rot mecessarily involved in such a change." FHA, UNDERWRITING MANUAL, par. 1320(2) (Rev. 1947) (emphasis added). See also Dean, supra note 22, at 430 n. 3; Sterner, The Negro's Srare 315-6 (1943); ABRAMS, THE Future OF Housing 400 n.10 (1946); cf. Crv. RTs. Rep. 70 (1947).

49. Mrrdal, AN AMerican Dremara 349 (1944). Thus far, for inesplicable reacons, neither the race discriminatory practices of the FPHA nor those of the FHA have resulted in litigation.

50. See, e.g., the New York Redevelopment Companies Law, N.Y. Laws 1943, c.234, \$2: Since slum conditions "cannot be remedied by the ordinary operations of private enterprise ... provisions must be made to encourage the investment of funds in corporations engaged in providing redevelopment facilities ..." In the absence of public intervention in the form of condemnation and tax subsidy it would not be economically feasible to build low rent housing in centrally located urban areas. See also Subsidy Taxation for Urban Rederelopment, American City, June, 1944, p. 76.

51. For an analysis of the complex of public and private elements which make up a redevelopment project, see Hearings before Conmillee on Banking and Currency on S. 1502, 79th Cong., 1st Sess. 485-524 (1945); FHA, A Handbook on Urban Redevelopiderit For Citres in the UNIted States 83-7 (1941); Mott, Urban Rederelopment Legislation Analyzed, American City, Aug. 1945, p. 83; Siegel, Real Properly Law and Mrass Housing Necds, 12 LAW \& Contesp. Prob. 30, 35-45 (1947); Comment, Urban Redetclopment, 54 YALE L. J. 116 (1944). 
The constitutional status of Stuyvesant Town can be determined through analysis of the purposes of the New York Redevelopment Companies Law and the interrelationship between municipality and redevelopment project which the law made possible. ${ }^{52}$ The New York statute provides that "the public interest requires the clearance, replanning, reconstruction and neighborhood rehabilitation" of slum areas. ${ }^{53}$ Twin purposes of the statute are slum clearance and moderate rental housing. To fulfill these purposes Now York City, under authority of the state statute, entered into a contract with Stuyvesant Town and its parent organization, Metropolitan Life Insurance $\mathrm{Co}^{54}$ The city contracted to use its eminent domain powers to condemn all buildings in a blighted area of 18 square blocks for transfer and sale to Stuyvesant Town. ${ }^{55}$ Condemnation proceedings forced some 3,000 families to leave the area. ${ }^{56}$ Since the statute defined the project as a "superior public use," even a public school was levelled at the request of Stuyvesant Town. ${ }^{57}$ Further, the city ceded 11 acres of public streets to the proj-

52. N.Y. Laws 1942 , c. 845 , as amended by 1943 , c. 234 . Upheld as constitutional in Murray v. LaGuardia, 291 N.Y. 320, 52 N.E.2d 884 (1943), cert. denied, 321 U.S. 771 (1944). The latter case only decided the constitutionality of the use of public power to aid privately owned redevelopment projects. Accord, Zurn v. Chicago, 389 I1l. 114, 59 N.E.2d 18 (1945); Simar v. O'Toole, 108 N.J.L. 32, 155 Atl. 449 (Sup. Ct. 1931), aff'd., 108 N.J.L. 549, 158 Atl. 543 (1932). See also, Miner, Some Constitutional Aspects of Housing Legislalion, 39 ILL. L. REv. 305, 335-9 (1945).

53. N.Y. Laws $1943, c .234, \S 2$. The section further reads: ". . . that the cooperation of the state and its subdivisions is necessary to accomplish such purposes; that the clearancc, replanning and reconstruction, rehabilitation and modernization of substandard and insanitary areas and the provision of adequate, safe, sanitary and properly planned housing accommodations in effectuation of official city plans . . . are public uses and purposes for which private property may be acquired for such corporations [e.g., Stuyvesant Town] and partial tax exemption granted ..."

54. Agreement of June 3,1943 (cited hereafter as Contract). In accordance with the enabling statute, the plans for Stuyvesant Town received both the approval of the State Commissioner of Insurance and the New York City Planning Commission on May 20, 1943, prior to the execution of the Contract by majority vote of the Board of Estimate. (On file with N.Y. City Board of Estimate.)

55. Contract $\$ 202$ provides that ". . . the City, at the request of the Corporation, shall institute all necessary proceedings to acquire by condemnation all of the real property" in the area ...."

56. Although Stuyvesant Town announced a policy of preference for the displaced families, this preference proved meaningless. According to testimony produced during Hearings before the Board of Estimale of New York City 38 (June 3, 1943) (cited hereafter as Transcript of Hearings), the inhabitants of the area could only afford to pay a rental of between five and seven dollars a room per month. Stuyvesant town's apartments rent for $\$ 17$ per room. Since no plan had been worked out to house these people, the Stuyvesant project inevitably caused the remaining slum areas to absorb them. In criticism of such planless development, see Carlson, Urban Redevelopment Legislation, American City, Nov. 1946, p. 93. See also note 60 infra.

57. N.Y. Laws 1943 , c. $234, \S 20$. Under the provisions of this section no building was sufficiently important to the public to escape the condemnation process. The result of condemning the public school is to force every child in the project to travel to schools outside the area. Transcript of Hearings 25. 
ect ${ }^{58}$ and granted it the power to police the development area with a private police force. ${ }^{59}$ Finally, the redevelopment project was granted a partial tax exemption of $\$ 50,000,000$ over a period of 25 years. ${ }^{c 0}$ In return, Stuyvesant Town contracted to erect a project to house 9,000 families, and submitted to governmental controls, including a $6 \%$ limitation on dividends ${ }^{01}$ and maintenance of moderate rent ceilings so long as it accepted the tax subsidy..$^{.2}$

On completion, Stuyvesant Town established a policy of racial exclusion. ${ }^{63}$ Three Negroes who desired to become tenants sought an injunction restraining the redevelopment company from barring Negroes. In denying the

58. In return for 759,861 square feet of public streets, Stuyvesant Toun transferred 234,412 square feet of land to the City to widen the surrounding street area. Net gift to the project: $11 \frac{1}{2}$ acres. Transcript of Hearizgs 23.

59. According to Stuyvesant's interpretation of the contract all streets in its area were to be plainly marked "private." The only person permitted to enter vithout parmission would be the City Comptroller who was to have the right to check the financial records periodically. Police, fire, playground services, etc., are all to be under the managementand control of the private corporation. Contract $\$ \$ 208,211,506$.

60. The corporation receives tax exemption for 25 years on the difference in value of the area before condemnation and the value of the new project. This involves a charge of $\$ 24$ over the 25 year period for every family in New York City. A number of housing critics attacked the project as a superior slum which would cost the city far more than it was worth. Abrays, The Future of Housung 321-2, 379 (1946); Rosesuas, A Mulios Houss A YEAR 202-3 (1945); Abrams, The Walls of Slugresanl Town, 160 Nation 328 (1945); Breines, Stuyvesant Tount, 4 TASK 35 (1943). For a favorable comment, see Afolropolitan Life Mroles Housing Pay, Fortune, April 1946, p. 133.

61. This compares with an average return on its other investments in 1916 of $3.01 \%$, 1946 Annual Report-ONe of Metropolitan's Greatest Years 15. See also Reed The Investment Policy of the Metropolitan Life, 4 TASK 38 (1945).

62. Once it gives up the tax subsidy-and pays all back taxes-the project may set its own rent. For the duration of the tax exemption Stuyvesant Town may raice rentals only after proving to the satisfaction of the Board of Estimate that it is maling less than the $6 \%$ for interest and amortization permitted by statute, (N.Y. Laws 1943, c. 234, $\$ 8$ ). Contract $\$ 504$ provides that if the Comptroller "finds that unreasonable expenditures for operation are being made, the City may request the Corporation to discontinue such expenditures." Additional statutory controls are: the project cannot be sold except as permitted by law (N.Y. Laws 1943, c. $234 \$ 23$ ); the city's approval must be obtained for any modification of the project (Id. §15); upon dissolution any cash surplus belongs to the city (Id. § 24); rigid controls are imposed over the financing of the Corporation. (Id. $\$ \S 9$ 12).

63. This policy was clearly foreshadowed by the statement that "Negroes and whites don't mix" made by Mr. Ecker, Chairman of the Board of Directors of Mietropolitan, quoted in Abrams, Race Bias in Housing, 165 Nation 67, 68 (July, 1947). The first case to challenge this early statement of policy was Pratt v. LaGuardia, 182 Misc. 462, 47 N.X.S. 2d 359 (Sup. Ct. 1941), aff'd, 268 App. Div. 973, 52 N.Y.S.2d 569 (1st Dep't 1944), leare lo appeal denied, 294 N.Y. 842, 62 N.E.2d 394 (1945). Since the project was not to be ready for three years, the action was held premature.

64. Dorsey v. Stuyvesant Town Corp., 118 N.Y.L.J. 163 (Sup. Ct. July 29, 1947). In answer to the complaint of Dorsey, Stuyvesant Town admitted its policy of racial exclusion. ". . . the successful operation of the project and the safety" of the investment of funds . . . require that Negroes should not . . . be accepted as tenants in this project." (p. 2 of Answer). However, it claimed "the usual powers of management vested in every" 
injunction the court relied on the two main arguments advanced by Metropolitan: first, that the public use and purpose was achieved when the new buildings had replaced the slum tenements; second, that legislative intent had been against limitation of the redevelopment company's managerial discretion in the selection of tenants. Thus, the project was held to be public until the time for occupancy; thereafter it was private and might establish a policy of racial exclusion. ${ }^{65}$ The result of the decision was to confirm Metropolitan's thesis that the proper legal status of Stuyvesant Town is that of a private home owner with an apartment to rent.

Assuming that the court's interpretation of statutory purpose ${ }^{\text {ff }}$ and intent ${ }^{67}$ is correct, the Sinyvesant Town opinion fails to meet squarely the basic constitutional issue created by such an interpretation. May a statute authorize such extensive state action-condemnation of 18 square blocks, displacement of 3,000 families, tax subsidy of $\$ 50,000,000$, gift of 11 acres

private corporation which owns and operates a private housing development, including the tight to select tenants of its own choice." (p. 5 of Answer).

65. The opinion also cited Dury v. Neely, 69 N.Y.S.2d 677 (Sup. Ct. 1947); Kemp v. Rubin, 188 Misc. 310, 69 N.Y.S.2d 680 (Sup. Ct. 1947); and Ridgway v. Cockburn, 163 Misc. 511, 296 N.Y.S.2d 936 (Sup. Ct. 1937), in which the New York courts had enforced racial restrictive covenants, as an argument in support of a private redeveloper's right to discriminate.

66. The opinion construed the purpose of the statute in a narrow physical sense. In holding that the statutory purpose was accomplished at the moment the buildings were constructed, the court ignored the broad implications of "neighborhood rehabilitation" required by the act. That the objective was to clear slums and provide for the housing needs of lower middle-class income groups is manifest in the continuing controls which the city maintains over the project. See note 62 supra.

67. Legislative intent was inferred from the following facts: (1) The State Constitutional Convention of 1938 refused to include a prohibition against discrimination, whenever state power and money were used, in the Housing Amendment (N.Y. CoNST. ART. Xvi1). Const. Conv. of 1938: Conv. Pr. Nos. 10, 18, 49, 203, 380, 625, 691. (2) While N.Y. Puntrc HousING LAW $\S 223$ prohibits discrimination in all projects which are wholly public, the legislature has consistently refused to consider amendments to the Redevelopment Companies Law which would affirmatively forbid discrimination in redevelopment projects. On numerous occasions bills to accomplish this purpose were buried in committce: 1944 Assem. Pr. Nos. 29, 416, 1321, 1469, 1996; 1945 Assem. Pr. No. 1885; 1947 Assem. Pr. No. 34. From the legislature's refusal to act against discrimination in redevelopment pro. jects, the court inferred an affirmative intent to permit discrimination. If the court had followed the techniques of statutory construction utilized in Steele v. Louisville \& Nashville R.R., 323 U.S. 192 (1944), it might well have inferred an opposite intent. See notes 69, 70 infra.

Metropolitan Life contended that without the power to discriminate it would not have invested the funds of its shareholders, since to so do would involve great financial hazard (Affidavit of Mr. Frederick Ecker, Pres., Board of Directors, Metropolitan Life, July 9 , 1947). However, this statement is contradicted by the fact that Metropolitan contracted to build the Riverton project soon after New York City passed an ordinance barring segregation in tax exempt projects (ADsr. CODE N.Y.C. $\$$ J41-1.2, July 3, 1944). This ordinance does not affect Stuyvesant Town since it is not retroactive. Two other redevelopment com* panies have contracted to build projects in spite of the ordinance. See Weaver, Planning For More Flexible Land Use, 23 J. LAND \& PUB. UT. Econ. 29, 40 n.22 (1947). 
of city property, surrender of municipal police power-in behalf of a private enterprise which intends to pursue a policy of racial exclusion? Stated differently, the issue is whether a redevelopment project, even though operated for private profit, is the kind of enterprise which must abide by a public standard.

That constitutional questions may arise when discrimination is practiced by an organization functioning under a statute was recognized by the Supreme Court in Steele v. Louisville \& Nashoille $R .{ }^{R} .^{C 3}$ Although the Court, in finding that the Railway Labor Act forbids anti-Negro discrimination by the Railway Brotherhoods, was not compelled to resolve the constitutional issue, ${ }^{69}$ Justice Murphy declared by way of concurrence that if the Labor Act did not forbid such discrimination, it would be unconstitutional under the ${ }_{4}^{r}$ Fifth Amendment. ${ }^{70}$ Extending the Steele case, a recent Kansas decision not only enjoined discrimination in bargaining but also ordered the union to grant full membership to Negro railway workers. ${ }^{71}$ Thus, the scope of "public" action was enlarged in order to prevent discrimination by a "private" organization; the position of Stuyvesant Town seems closely analogous.

Moreover, a constitutional issue similar to the issue not discussed in the Stuyvesant Town opinion was resolved by the Supreme Court in Snith v. Allwright..$^{22}$ The denial by a political party of the right of a Negro to vote in its primary was held unconstitutional because the party was considered a "state agency." 73 Since the political party was subject to legislative controls and had received legislative benefits, the party had to act in accordance with the constitutional standard required of the legislature, the ultimate

68. 323 U.S. 192 (1944).

69. "If, as the state court has held, the Act confers this power [to discriminate] on the bargaining representative . . . without any commensurate statutory duty toward its mem. bers, constitutional questions arise. . . . But we think that Congress, in enacting the Railway Labor Act and authorizing a labor union, chosen by a majority of a crit . . . did not intend to confer plenary power upon the union to sacrifice, for the benefit of its members, rights of the minority of the craft, without imposing any duty to protect the minority." Id. at $198-9$.

70. "The Act contains no language which directs the manner in which the bargaining representative shall perform its duties. But it cannot be assumed that Congress meant to authorize the representative to act so as to ignore rights guaranteed by the Constitution. Otherwise the Act would bear the stigma of unconstitutionality under the Fifth Amendment." Id. at 208.

71. Betts v. Easley, 161 Kan. 459, 169 P.2d 831 (1946), 56 YALE L. J. 731 (1947).

In Williams v. International Brotherhood of Boilermalsers, 27 Cal.2d 586, 591-2,165 P.2d 903, 906 (1946) an injunction was granted against a closed shop agreement obtained by a union which practiced segregation: "The public interest is direetly involved breause the unions are seeking to control by arbitrary selection the fundamental right to vorls . . . although such a labor monopoly is not in itself improper, it carries with it certain responsibilities, and the public clearly has an interest in preventing any abuse of it."

72. 321 U.S. 649 (1944).

73. "The party takes its character as a state agency from the duties imposed upon it by state statutes..." Id.at 663 . 
source of its authority. Since the state legislature could not discriminate on a racial basis, its instrumentality was similarly enjoined.

The similarity between the Allwright situation and the administration of redevelopment projects such as Stuyvesant Town seems clear. Taking a broad view of the nature of a "state agency," the Court recognized in the former case that suffrage is a matter of such importance that a minimum of state regulation is sufficient to alter the constitutional status of a private organization. It would seem that housing is no less important than the right to vote. ${ }^{74}$ The quantum of governmental regulation of Stuyvesant Town appears far greater than its counterpart in the Allwright case. While it seems probable that the political party could function satisfactorily without legislative controls and benefits, ${ }^{75}$ Stuyvesant Town could never have been realized without the public aid and power extended by legislation. ${ }^{76}$ Since state action was an essential element in the creation of Stuyvesant Town, it would seem that the entire enterprise might be considered an instrumentality of the state and thus subject to the constitutional standard required of government itself. To decide otherwise means that a private project can have the benefits of public subsidy and power, together with the privilege of race discrimination.

Perhaps the most suggestive analogy to the Stuyvesant Town case is Marsh v. Alabama, in which the property rights of a company town were held subservient to basic rights guaranteed by the Fourteenth Amendment. ${ }^{77}$ There the Supreme Court held that a privately owned town could not prevent the dissemination of religious literature. While in this decision only religious and political liberty were protected, the decision would appear most logically to require company towns to abide by all the standards of the Fourteenth Amendment, including the equal protection clause. In effect, Stuyvesant Town is similar to a company town..$^{78}$ In the area it covers Stuyvesant

74. "Housing is a necessary of life. All the elements of a public interest justifying some degree of public control are present." Holmes, J., upholding the Rent Control Act of 1919 for the District of Columbia, in Block v. Hirsh, 256 U.S. 135, 156 (1921).

75. Following the decision in the Allwright case, South Carolina repealed all state statutes which regulated the conduct of political parties and primaries. Nonetheless, in Elmore v. Rice, 72 F. Supp. 516 (D.S.C. 1947), the court still treated the Democratic party as a state instrumentality and ordered the party to enroll Negroes and permit them to vote in the primaries.

76. See pp. 438-9 supra.

77. 326 U.S. 501 (1946). See pp. 453-4 infra for a more detailed interpretation of the casc.

78. Another suggestive analogy to redevelopment housing is the public utility. 'The characteristics which distinguish public utilities from other private enterprises are first, that they are in a monopoly or near monopoly position with regard to control over a vital service; second, that they are in this position because of governmental action or acquiescence; and third, that they are so affected with the public interest as to require the application of a non-private standard. Thus, the courts would surely enjoin an electric company from refusing its services on purely racial grounds. Todd v. Citizens' Gas Co. of Indianapolis, 46 F. 2d 855, 866 (C.C.A. 7th 1931); Philadelphia Rural Transit Co. v. Philadelphia, 309 Pa، 84, 91-2, 159 Atl. 861, 863-4 (1932). See also People ex rel. Western Union v. Public Service 
Town is responsible for police protection, and makes such vital decisions as whether there shall be a school or library. In short, it establishes the cultural environment for a community of 9,000 families. Since Stuyvesant Town has assumed much of the character of government, standing in a relation to New York City similar to that of the company town in relation to its state government, its status as a private government would appear to impose on it constitutional obligations. Among these obligations would seem to be the requirement that the housing development open its doors to tenants on a non-racial basis. ${ }^{79}$

Without such a requirement, the validity of the contract between the city and Metropolitan is open to constitutional attack. ${ }^{80}$ Since the Board of Estimate voted for the contract in spite of clear notice of Stuyvesant's intent to discriminate, it would be difficult to argue that the discrimination was only an incidental by-product of the redevelopment agreement. ${ }^{82}$ Having entered into the agreement with knowledge of Stuyvesant's policy of racial exclusion, the city would seem to have effected racial zoning for a specific area by contract. To hold such a contract invalid, it is only necessary to cite Harmon $v$. Tyler, which declared unconstitutional an ordinance that, in effect, granted private home owners the power to zone racially. ${ }^{82}$ Whatever the means employed, whether the Board of Estimate votes for an ordinance or a contract, municipal action resulting in racial zoning seems a denial of equal protection.

The problem of remedy remains. If the assumption in the Stugresont Toun

Comm., 230 N. Y. 95, 129 N. E. 220 (1920); Consumers Light and Power Co. v. Phipps, 120 Okla. 223, 225, 251 Pac. 63, 65 (1926): "Under the common law, it was the duty of all persons engaged in a 'public business' to treat all members of the public fairly and without discrimination. . ." See also Marsh v. Alabama, 326 U. S. 501, 506 (1946); cases collected in Barnes, Cases on Public Utiltty Regulations $\$ \$ 1.01-1.09$ (1934); 1 MicQuillis, MUNiCIPAL CoRporations 371 (Rev. ed. 1940).

79. For a discussion of the Allworight, Steele and Jfarsin cases see Hale, Rights $U$ nder the Fourteenth and Fifteenth Anrendments Agdinst Injuries Inflicled by Pritale Irdicidnols, 6 LAW. GuILD REv. 627 (1946).

80. In Polier v. O'Dwyer, 118 N.Y.L.J. 796 (Sup. Ct. Oct. 9, 1947), Justice Benvenga rejected a taxpayer's plea to have the tax exemption provisions of the contract declared invalid primarily on the ground that all constitutional issues had been settled by his opinion in Dorsey v. Stuyvesant Town, 118 N.Y.L.J. 163 (Sup. Ct. July 29, 1947).

81. See Transcript of Hearings (passinz). In the course of the Hearings witnes after witness charged that Metropolitan Life intended to discriminate and hence recommended that the Board of Estimate vote against the redevelopment agreement. Commissioner of Parks Mioses defended the corporation's right to discriminate. Transcripl of Hearings 9-10. In voting in the negative Newbold Morris stated his reason as follows: "Therefore, beeause I care more about the principle than I do about the project, because I cannot vote for public aid and public sponsorship of a private project, whose officers state with candor that racial consideration will enter into the selection of tenants, I cast the three votes of my office in the negative." The final vote was 11 to 5 in favor of the contract.

82. 273 U.S. 668 (1927). See p. 435 supra. In the Stuyresant Toum case the City accomplished this result by contract, granting the power to exclude racially to the Board of Directors of the redevelopment company. 
opinion as to the intent of the New York Legislature is accepted, the statute would appear unconstitutional. ${ }^{83}$ Alternatively, a constitutional intent may be assumed, but the contract between the city and Stuyvesant Town may still be declared invalid on the ground that the municipality, an agency of the state, acted in aid of discrimination. ${ }^{84}$ Finally, Stuyvesant Town itself may be treated as an instrumentality of the state. The statute and the contract may be considered constitutional, but the discriminatory conduct of the "state agency" enjoined. Since the project is almost completed, practicol considerations would call for the last approach.

In contrast with New York State practice, Pennsylvania legislation governing urban redevelopment projects provides positive assurance that on completion such projects will be open to members of all races equally. Utilizing the covenant device in reverse, the Pennsylvania statute requires that all redevelopment contracts between cities and private redevelopers include " a covenant running with the land to the effect that no person shall be deprived of the right to live in the redevelopment project . . . by reason of race, color, or national origin. . . ." 85

\section{Segregation by Private Agreement}

The most widely used legal device for accomplishing race segregation in housing is the restrictive covenant, a mutual agreement among land owners not to sell the restricted property to, nor to allow its use by, members of designated races. ${ }^{86}$ Typically, the covenants cover an entire subdivision or

83. Under the doctrine of Yick Wo v. Hopkins, 118 U.S. 356 (1886), the statute could be declared unconstitutional on the ground that, although neutral on its face, it was administered in such a way as to deny the law's equal protection to Negroes. $A$ forliori, this result must follow if the legislature intended to distribute the housing benefits of urban redevelopment on a racial basis.

84. The same court which decided the Stuyvesant Town case denied a taxpayer's suit brought to enjoin the city from granting Metropolitan the tax benefits called for by the contract. See note $\mathbf{8 0}$ supra. Both cases have been appealed and will probably be heard by the Appellate Division in February or March, 1948. Communication to the Yale Law Journal from the American Jewish Congress, Dec. 5, 1947.

85. Pennsylvania Urban Redevelopment Law, PA. StaT. ANN., tit. 35, $\S 1701, \S 1711$ (Purdon, Supp. 1946). See also Administrative Code of NEw York CiTY, $\S$ J41-1.2, July 3,1944, which denies tax exemption to future projects which discriminate. Available data indicate that Pennsylvania and New York City are the only jurisdictions which affirmatively outlaw segregation in redevelopment projects.

86. "The form of the covenant is immaterial. . ." Mays v, Burgess, 147 F.2d 869, 872 (App. D.C. 1945), cert. denied, 325 U.S. 868 (1945). See also, e.g., Letteau v. Ellis, 122 Cal. App. 584, 588, 10 P.2d 496, 497 (1932) (difference between "conditions, covenants and mere restrictions" immaterial); Edwards v. West Woodridge Theater Co., 55 F.2d 524, 525(App. D.C. 1931) (equity will enforce a general plan reflecting only parol agreement); Northwest Civic Ass'n v. Sheldon, 317 Mich. 416, 27 N.W.2d 36 (1947) (immaterial that restriction not in chain of title); but of. United Cooperative Realty Co. v. Hawkins, $269 \mathrm{Ky} .563,108$ S.W.2d $507^{\circ}$ (1937), where the difference between agreement and deed was decisive in suit for recission of land sale.

In most cases the restriction is enforced as an equitable servitude, so that actual notice 
desirable street frontage, ${ }^{87}$ and are directed chiefly at Negroes. ${ }^{89}$

The typical restrictive covenant case has the following steps: sale of a home in a restricted area to a Negro, occupancy, suit in equity by a neighbor seeking specific performance of the covenant. Unless there has been some technical defect in the covenant, ${ }^{69}$ the courts will force the Negro to move. Change in circumstance is the usual ground for non-enforcement, but the change must be "radical," ${ }^{90}$ and some courts insist that the change be in property covered by the covenants rather than the surrounding property, ${ }^{21}$ a requirement that seems almost impossible to fulfill.

Cases now awaiting decision by the Supreme Court illustrate the typical settings of restrictive covenant litigation. In each case a white vendor was enjoined from transfering or a Negro purchaser from occupying covenanted property. In Kraemer v. Shelley, ${ }^{22}$ the Missouri Supreme Court upheld a covenant signed by 30 of 39 owners in a St. Louis block, imposing a 50-year restriction against sale or occupancy by Negroes or Mongolians. A perma-

is not required; e.g., Wayt v. Patee, 205 Cal. 46, 269 Pac. 660 (1928). See Clarrs, Real COVENANTS AND OtHER INTERESTS WHICH "RUN WitTH LAND" 170-S6 (1947).

87. See note 22 supra.

88. A restriction against Negroes has been implied from a covenant direeted against those "whose ownership or occupancy would be injurious to the locality." Schulte v. Starks, 238 Mich. 102, 213 N.W. 102 (1927); but of. Kathan v. Stevenson, 307 Mich. 485, 12 N.WV.2d 332 (1943), Kathan v. Williams, 309 Mich. 219, 15 N.W.2d 137 (1944). Prevailing custom was decisive in Wyatt v. Adair, 215 Ala. 363, 110 So. 801 (1926) (white tenant recovers damages when his landlord leased an apartment in the same building to Negross, despite lack of express agreement).

89. E.g., Foster v. Stewart, 134 Cal. App. 482, 25 P.2d 497 (1933) (number of signatories inadequate to achieve implied general plan); accord, Thornhill v. Herdt, 130 S.IW.2d 175 (St. Louis Ct. App. 1939). Oberwise v. Poulos, 124 Cal. App. 247, 12 P.2d 156 (1932) (number of signatories specified in instrument not obtained); DuRoss v. Trainor, 122 Cal. App. 732, 10 P.2d 763 (1932) (too indefinite a description of the property; inadequate proof of signature); Stratton v. Cornelius, 99 Cal. App. 8, 277 Pac. 893 (1929) (sale permissible where covenant specified only renting and leasing); Scholtes v. MicColgan, 184 MId. 480, 41 A.2d 479 (1945) (no showing of general plan). See Jones, Legalily of Race Restrictire Housing Cozenants, 4 NAT. BAR J. 14, 24-5 (1946); Miller, Race Restriclions on the Use or Sole of Resl Property, 2 Nat. Bar J. 24, 29-30 (1944).

90. Compare Dooley v. Savannah Bank \& Trust Co., 199 Ga. 353, 362, 34 S.E.2d 522, 528 (1945) (no averment of sufficiently radical change; covenant enforced) will Piclel v. McCawley, 329 Mo. 166, 176, 44 S.W.2d 857, 861 (1931) (radical change defeats purpose of covenant; enforcement denied).

91. The most dramatic example is Vernon v. Reynolds Realty Co., 226 N.C. 58, 36 S.E.2d 710 (1946), where the builders could not avoid their self-imposed covenant since there had been no breach in the subdivision, although the surrounding neighborhood had become Negro. Other examples are: Swain v. Maxwell, 196 S.W.2d 780 (Mo. 1946); Porter v. Pryor, 164 S.IW.2d 353 (Mo. 1942). Compare Shideler v. Roberts, 69 Cal. App.2d 549, 160 P.2d 67 (1945) with Fairchild v. Raines, 24 Cal.2d 818, 151 P.2d 260 (1944) and Letteau v. Ellis, 122 Cal. App. 584, 10 P.2d 496 (1932). Compare Grady v. Garland, 89 F.2d 817 (App. D.C. 1937) with Hundley v. Gorewitz, 132 F.2d 23 (App. D.C. 1942). See, Note, Negro Restrictions and the "Changed Conditions" Doctrine, 7 U. of Crr. L. REv. 710 (1940).

92. 198 S.W.2d 679 (Mo. 1946), cert. granted, 67 Sup. Ct. 1751 (1947), Justice Reed taking no part. 
nent restriction against sale or rental to Negroes in a District of Columbia block was sanctioned in Hurd v. Hodge.93 The Michigan Court in Sipes ข. $M c G h e e^{94}$ upheld a 25-year restriction against use and occupancy by Negroes of a Detroit property. These three cases-in each of which the United States appeared amicus favoring reversal-have already been argued. ${ }^{95}$ In three other cases, petitions have been filed requesting certiorari. In Perkins $v$. Trustees of Monroe Avenue Church of Christ, ${ }^{96}$ the race covenant was held unenforcible against an incorporated church on the ground that a corporation can have no racial identity, ${ }^{97}$ but the eviction of the Negro minister of the racially mixed congregation was ordered. A Chinese and a Korean are the petitioners in the other two cases against the Superior Court of California for Los Angeles County. ${ }^{98}$

These cases are typical of American decisions in result and reasoning. In all but one of the 21 jurisdictions in which the issue has arisen, the enforcement of racial restrictive covenants has been upheld. ${ }^{99}$ The general

93. 162 F.2d 233 (App. D.C. 1947), cert. granted, 68 Sup. Ct. 100 (1947).

In 62 American covenant cases in which the duration of the restriction was mentioned, 44 of the restrictions were permanent, by either express provision or failure to mention a terminal date. Two cases have been found in which enforcement was denied because a permanent restriction was involved. Williams v. Commercial Land Co., 34 Ohio L. Rep. 559 (Ohio App. 1931); Yoshida v. Gelbert Improvement Co., 58 Pa. D. \& C. 321 (1946).

94. 316 Mich. 614, 25 N.W.2d 638 (1947), cert. granted, 67 Sup. Ct. 1754 (1947), Justice Reed taking no part.

95. Justices Jackson, Reed and Rutledge disqualified themselves from hearing the cases, N. Y. Herald Tribune, Jan. 16, 1948, p. 1, cols. 3-4. For accounts of the argument, see 16 U.S.L. WeEk 3219-24 (U.S. Jan. 20, 1948).

96. 79 Ohio App. 457, 70 N.E.2d 487 (1946), appeal dismissed for lack of "debatable constitutional question," 147 Ohio St. 537, 72 N.E.2d 97 (1947), pet'n for cerl. filed, June 26, 1947, 16 U.S.L. WEEK 3058 (U.S. Aug. 12, 1947).

97. Citing, at 70 N.E.2d 490-1, People's Pleasure Park Co. v. Rohleder, 109 Va. 439, 61 S.E. 794 (1908) (sale to corporation composed of Negroes intending to operate an amusement park for Negroes not violation of restrictive covenant) and Continental Tyre and Rubber Co., Ltd. v. Daimler Co., Ltd. [1915] 1 K.B. 893 (though all directors and all stockholders but one are Germans resident in Germany, Corporation is not enemy alien). These cases seem to suggest self-incorporation as an effective method of evading restrictive covenants.

98. Amer. v. Sup'r Ct. and Yin Kim v. Sup'r Ct., unreported below, were decided Aug. 21, 1947, petition for certiorari having been filed on Nov, 6, 1947. 16 U.S.L. WEEK 3173 (U. S. Nov. 25, 1947).

99. The constitutionality of judicial enforcement of restrictive covenants has been considered by the highest courts of fifteen jurisdictions. The leading cases are: Fairchild v. Raines, 24 Cal.2d 818, 151 P.2d 260 (1944); Los Angeles Investment Co. v. Gary, 181 Cal. 680, 186 Pac. 596 (1919); Chandler v. Ziegler, 88 Colo. 1, 291 Pac. 822 (1930); Hurd v. Hodge, 162 F.2d 233 (App. D.C. 1947), cert. granted, 68 Sup. Ct. 100 (1947); Mays v. Burgess, 147 F.2d 869 (App. D.C. 1945), cert. denied, 325 U.S. 868 (1945), Reed and Jackson, JJ., not participating, Murphy and Rutledge, JJ., dissenting; Dooley v. Savannah Bank \& Trust Co., 199 Ga. 353, 34 S.E.2d 522 (1945); United Cooperative Realty Co. v. Hawkins, 269 Ky. 563, 108 S.W.2d 507 (1937); Queensborough Land Co. v. Cazeaux, 136 La. 724, 67 So. 641 (1915) (first state case); Meade v. Dennistone, 173 Md. 295, 196 Atl. 330 (1938); Sipes v. McGhee, 316 Mich. 614, 25 N.W.2d 638 (1947), cert. granted, 67 Sup. Ct. 1754 (1947); Porter v. Barrett, 233 Mich. 373, 206 N.W. 532 (1925); Kraemer v. Shelley, 198 
rationale is that the law should enforce private agreements where there is no contrary policy.

An argument frequently made against the enforceability of restrictive covenants is that they impose unreasonable restraints on alienation. ${ }^{100} \mathrm{~A}$

S.W.2d 679 (Mo. 1946), cert. granted, 67 Sup. Ct. 1751 (1947); Koehler v. Rowland, 275 Mo. 573, 205 S.W. 217 (1918); Phillips v. Wearn, 226 N.C. 290, 37 S.E.2d 895 (1946); Lyons v. Wallen, 191 Okla. 567, 133 P.2d 555 (1942); White v. White, 108 W. Va. 128, 150 S.E. 531 (1929). Clear dicta supporting race covenants appear in Wyatt v. Adair, $215 \mathrm{Ala} .363$, 110 So. 801 (1926). In two cases the approval of race covenants was not directly before the court but was implicit in the decision of litigation dealing with tax deficiency land sales. Ocean Beach Improvement Co. v. Jenkins, 142 Fla. 273, 194 So. 787 (1910); Doherty v. Rice, 240 Wis. 389, 3 N.W.2d 734 (1942). (In Clark v. Vaughan, 131 Kan, 438, 292 Pac. 783 (1930), denying enforcement because of change in conditions, the parties raised no issues concerning the enforceability of the covenant; in Peoples' Pleasure Park Co. v. Rohleder, 109 Va. 439,61 S.E. 794 (1908), the court assumed but did not decide the legitimacy of the covenant, in refusing to enforce it against a corporation composed of Negroes.)

In five states approval of covenants rests on lower court decisions. Burke v. Kleiman, 277 Ill. App. 519 (1934), aff'd on other grounds sub nom. Lee v. Hansberry, 372 IIl. 369, 24 N.E.2d 37 (1939), rev'd, 311 U.S. 32 (1940) (res judicata only issue considered); Lion's Head Lake v. Brzezinski, 23 N.J. Misc. 290, 43 A.2d 729 (Dist. Ct. 1945); Kemp v. Rubin, 188 Misc. 310, 69 N.Y.S.2d 680 (Sup. Ct. 1947); Ridgeway v. Cockburn, 163 Misc. 511,296 N.Y. Supp. 936 (Sup. Ct. 1937); Perkins v. Trustees of Monroe Ave. Church, 79 Ohio App. 457, 70 N.E.2d 487 (1946), appeal dismissed, 147 Ohio St. 537, 72 N.E. 2d 97, (1947), pet'n for cert. filed, 16 U.S.L. WEEK 3058 (U. S. Aug. 12, 1947); Crump v. Perry'man, 193 S.W.2d 233 (Civ. App. Tex. 1946).

Pennsylvania is the sole American jurisdiction in which covenants are apparently denied enforcement. Although the only two cases found, both in inferior courts, involved permanent restrictions on sale, the language of the opinions seems broad enough to include all racial restrictions. Yoshida v. Gelbert Improvement Co., 58 Pa. D.\&.C. 321 (1946); Ellsworth v. Stewart, 9 Erie County L. J. 305 (Pa. 1928). See Notes, 162 A.L.R. 180 (1946); 114 A.L.R. 1237 (1938); 66 A.L.R. 531 (1930); 9 A.L.R. 120 (1920).

In the absence of judicial action, official committees appointed by Presidents Hoover and Truman both recommended legislation barring restrictive covenants. Presidest's Conference 115; Crv. RTS. REP. 169. That the legislature has the constitutional power to enact such legislation seems clear in the light of the modifications of private property rights upheld in the use zoning cases, and in Railway Mail Ass'n v. Corsi, 326 U.S. 88 (1945). The initial attempt to enact anti-covenant legislation was apparently the amendment proposad last year to the Denver City Charter. This amendment was defeated by a close rote in committee. Rocky Mountain News, Oct. 9, 1947, p. 5, col. 4. In action by a city rather than a state, the primary legal problem is whether a municipality has sufficient power delegated from a state. In the case of Denver, the home rule provisions of the state constitution appear broad enough to sustain city action. CoLo. Cossr. Art. XX, $\$ 1$; $f$. MrCormicls v. Montrose, 105 Colo. 493, 99 P. 2d 969 (1939).

100. "Under this restriction a purchaser, in order to ascertain whether he was competent to take title, would have to trace back his lineage and ascertain if any, even to the remotest degree, he had in his veins the blood of any of the restricted classes of persons named, which, I am afraid, would be impossible for the most of us. . . . If this restriction is valid, then one which excluded as well those of English, Irish, Scotch, German, French or Swedish deseent would as well be valid. Is it possible that such a restriction in a deed could be a valid one? We can reach no other conclusion than that the restriction in this deed is an unressonable restraint of alienation, against public policy and void." Ellsworth v. Stewart, 9 Eric County L. J. 305, 311 (Pa. 1928). For discussions of the property doctrines, see Bowman, The Con- 
few courts have accepted this argument to the extent of refusing to enforce covenants against sale while sanctioning covenants against use and occupancy. ${ }^{101}$ Since it is unlikely that a Negro would buy property on which neither he nor his race can live, a covenant against use and occupancy seems just as effective a restraint as a covenant against sale. Such a distinction thus appears unrealistic. ${ }^{102}$

However, most courts dismiss the argument that race covenants involve unreasonable restraints on alienation by analogizing them to other restrictive covenants,such as those against certain architectural types and industrial use. Both types, it is argued, equally reflect private property rights. However, the obvious difference between restrictions on land use and restrictions against racial occupancy makes this rationale seem meaningless. Moreover, the Supreme Court's decisions upholding zoning ordinances based on land use but invalidating those based on racial occupancy renders the rationale untenable. ${ }^{103}$

The chief argument urged in the current cases against race covenants is that their judicial enforcement violates the Federal Constitution. Although the Supreme Court's decision in Corrigan v. Buckley ${ }^{104}$ has been considered by the great majority of state opinions as foreclosing this attack, actually the issue was not decided by the Court. The defendants who were enjoined from selling and accepting title to the covenanted District of Columbia property argued only that the covenant per se was unconstitutional. In affirming the injunctive decree, the Supreme Court thus only decided that the signing of covenants was not interdicted by the Constitution. ${ }^{105}$ Since

stitution and Common Law Restraints on Alienation, 18 B.U.L.Rev. 1 (1928); Bruce, Racial Zoning by Private Contract in the Light of the Constitutions and the Rule Against Restraints on Alienation, 21 ILL. L. Rev. 704 (1927); McGovney, Racial Residential Segregation by Stato Court Enforcement of Restrictive Agreements, Covenants or Conditions in Decls is Unconstitutional, 33 CALIF. L. REv. 5, 6 (1945), esp. at 9 n.17.

101. Los Angeles Investment Co. v. Gary, 181 Cal. 680, 186 Pac. 596 (1919); Porter v. Barrett, 233 Mich. 373, 206 N.W. 532 (1925); White v. White, 108 W. Va. 128, 150 S.E. 531 (1929); cf. Meade v. Dennistone, 173 Md. 295, 196 Atl. 330 (1938).

In the only case found which deals with the definition of "occupancy," it was held that there was no violation of a racial covenant in the state's building a fishing site to be open to all members of the public. Gableman v. Dep't of Conservation, 309 Mich. 416, 15 N.W.2d 689 (1944).

102. See Miller, Race Restrictions on Ownership or Occupancy of Land, 7 LAw. GurLd REv. 99, 101-2 (1947).

103. Compare Euclid v. Ambler Realty Co., 272 U.S. 365 (1926) wilt Buchanan v. Warley, 245 U.S. 60 (1917) which was extended in Harmon v. Tyler, 273 U.S. 668 (1927) and Richmond v. Deans, 281 U.S. 704 (1930), both of which were handed down subsequent to the Euclid decision.

104. 271 U.S. 323 (1926).

105. "Under the pleadings in the present case the only constitutional question involved was that arising under the assertions in the motions to dismiss that the indenture or covencent . . . is 'void' in that it is contrary to and forbidden by the Fifth, Thirteenth and Fourteenth Amendments. . . . It is obvious that none of these Amendments prohibited private individuals from entering inlo contracts respecting the control and disposition of 
the contention that state action was involved in the plaintiff's involing the aid of a court to give effect to the covenant was not raised until the case was before the Supreme Court, the Court refused to consider the argument and dismissed for want of jurisdiction. Although there is a brief indication that its view on this issue might have been adverse to the defendants, ${ }^{100}$ the Court concluded with a clear declaration that it had not considered the merits of the court enforcement issue. ${ }^{107}$ Moreover, since the case arose in the District of Columbia and thus could involve only the Fifth Amendment, it adjudicated nothing concerning the applicability of the equal protection clause of the Fourteenth Amendment. ${ }^{105}$ The issue is thus open for a fresh legal appraisal. ${ }^{109}$

There is evidence indicating that the framers of the Fourteenth Amend-

their own property; and there is no color whatever for the contention that they render the indeniure void." 271 U.S. at 329-30 (emphasis added).

106. "And, while it was further urged in this Court that the decrees of the courts below in themselves deprived the defendants of their liberty and property without due process of law, in violation of the Fifth and Fourteenth Amendments, this contention lilsewise cannot serve as a jurisdictional basis for the appeal. Assuming that such a contention, if of a substantial character, might have constituted ground for an appeal under paragraph 3 of the Code provision, it was not raised by the petition for the appeal or by any assignment of error, either in the Court of Appeals or in this Court; and it likervise is lacking in substanee." 271 U.S. at 331 (emphasis added).

107. ". . . we cannot determine upon the merits the contentions . . . that the indenture is not only void because contrary to public policy, but is also of such a discriminatory character that a court of equity will not lend its aid by enforcing the specific performance of the covenant . . . the appeal must be, and is Dismissed for crant of jurisdiclion." Id. at 332.

108. Although the language of the Corrigan opinion quoted in note 105 supre indieates that the pleadings were in part based on the Fourteenth Amendment, Wight v. Davidson, 181 U.S. 371, 384 (1901) had already decided that the Fourteenth Amendment does not apply to the District of Columbia. The Supreme Court has said there is no equal protection clause in the Fifth Amendment. Hirabayashi v. United States, 320 U.S. 81, 100 (1943); Detroit Bank v. United States, 317 U.S. 329, 337-8 (1943) and cases therein cited; Truax v. "Corrigan, 257 U.S. 312, 340 (1921). But cf. "The Fifth Amendment as applied to the District of Columbia implies equal protection of the laws." Sims v. Rives, S4 F.2d \$71, 378 (App. D.C. 1936), cert. denied, 298 U.S. 682 (1936). For discussion of whether the District is a "state" for other purposes, see Notes, 55 YALE L. J. 600 (1946); 46 CoL. L. Rev. 125 (1946); Federal Legislation, 29 GEO. L. J. 193 (1940).

109. Legal writers agree that Corrigan v. Buckley decided nothing about the constitutionality of state court enforcement of restrictive covenants. E.g., Bowman, The Constitrstion and Common Law Restraints on Alienation, \& B.U.L. REv. 1, 2 (1928); McGovney, Racial Residential Segregation by Stale Court Enforcement of Restriclite Agrcements, Cotenants or Conditions in Deeds is Ustconstitutional, 33 CALIF. L. REv. 5, 6 (1945); Comment, Constitutional Lavo-State Court Enforcement of Race Restrictire Cotcrants as Stale Action within Scope of Fourteentlz Amendment, 45 MrCH. L. REv. 733, 738-9 (1947) (best defense of prevailing judicial view).

The General Counsel of the National Association of Real Estate Boards, a consistent defender of race covenants, in a letter of Miay 4,1927, wrote, "The objection that such restrictions are of such a discriminatory character that a court of equity will not aid was raised in the Corrigan case but was not decided."

Although Doherty v. Rice, 240 Wis. 389, 396-7, 3 N.IW.2d 734, 737 (1942) refers to the 
ment conceived it as an effective weapon against any state aid to discrimination, apparently including discrimination by groups or individuals. ${ }^{110}$ Civil rights legislation enacted to implement this wide anti-discrimination purpose, although in part subsequently declared unconstitutional, ${ }^{111}$ scems a further indication that the legislators of the reconstruction period held no narrow view of the Fourteenth Amendment. Still in effect is a civil rights act providing that: "All citizens . . . shall have the same right . . . as is enjoyed by white citizens ... to inherit, purchase, lease, sell, hold, and convey real and personal property." 112 Although this statute has not been given serious consideration in state court covenant opinions, ${ }^{113}$ it seems to reflect an anti-discrimination doctrine comprehensive enough to include restrictive covenants. ${ }^{114}$

This broad conception of the Amendment was recognized in Gandolfo v. Hartman, ${ }^{115}$ the first case involving the constitutionality of restrictive cov-

Corrigan case as "finally settling" the constitutional issue, an increasing volume of litigation indicates that such is far from the fact. Of 72 American cases found, 22 were decided in the decade following the Corrigan decision, while 41 have been decided since 1937.

110. See Flack, The Adoption of the Fourteentu Amendment (1908); Swisuer, American Constitutional Development 329-34 (1943); Warsoff, Equality and Tile LAw (1938); Boudin, Truth and Fiction About the Fourteenth Amendment, 16 N.Y.U.L.Q. REv. 19, 35-6, 75, 79 (1938); Graham, The "Conspiracy Theory" of the Fourteenth Amendment, 47 YALE L.J. 371, 381, 387-8, 401-3 (1938). See also Appendix to dissenting opinion of Mr. Justice Black in Adamson v. California, 67 Sup. Ct. 1672, 1684, 1696 (1947).

111. Civil Rights Cases, 109 U.S. 3 (1883). For the history and present status of these statutes generally, see Konvitz, The Constitution and Civil Rights 3-106 (1947); Biddle, Civil Rights and the Federal Law in SAFEgUarding Civil LiberTy TOdAY 109 (1945); Clark, A Federal Prosecutor Looks At the Civil Rights Statutes, 47 Col. L. Rev. 175 (1947); Lee, Federal Protection of Civil Liberties, 1 Edit'L RESEARCH REP. 27 (1947).

112. 14 STAT. 27 (1866), 8 U.S.C. $\$ 42$ (1940).

113. The most likely explanation is that these courts have applied here also the broad interpretation of "private" action they have read into the Fourteenth Amendment. In terms of precedent this is a paradoxical view because the Supreme Court decision cited to sustain this view, the Civil Rights Cases, apparently made an express exception for this statute. "An individual cannot deprive a man of his right to vote, to hold properly, to buy and sell, to sue in the Courts, or to be a witness or a juror, . . ." except under some state action, which would be unconstitutional, 109 U.S. 3, 17 (1883) (emphasis added). This statute was cited in Buchanan v. Warley, 245 U.S. 60,78 (1917). Recently it has been revived in Oyama v. California, 16 U.S.L. WEEK 4108 (U. S. Jan. 20, 1948), and in two state decisions. State v. Ikeda, 61 Ariz. 41, 143 P.2d 880 (1943) (requirement that dealings with Japanese-Americans be publicized held a violation of the statute); Crist v. Henshaw, 163 P.2d 214 (Okla. 1945) (sale of land to Negro, even in white neighborhood, cannot be a "nuisance," in face of Civil Rights Act).

114. "Since the injunctions are based on covenants alone and the covenants are based on color alone, ultimately the injunctions are based on color alone. Even if they were based on color in combination with other factors they would still violate the Act. The Act prohibits injunctions which depend in any degree upon the fact that the persons enjoined are colored, for any restriction which is imposed upon the right of colored citizens to purchase and hold property and would not be imposed upon the right of white citizens to purchase and hold the same property denies to colored citizens 'the same right . . . as is enjoyed by white citizens.' " Edgerton, J., dissenting, Hurd v. Hodge, 162 F.2d at 241 (App. D.C. 1947).

115. 49 Fed. 181 (S.D. Cal. 1892). 
enants, where a United States circuit court concluded, as an alternative ground of decision, ${ }^{116}$ that to regard the enforcement of race covenants as not prohibited by the Fourteenth Amendment would be to give too narrow a scope to the Amendment's broad sweep. ${ }^{117}$ Moreover, on the basis of this policy implicit in the Fourteenth Amendment, two recent Los Angeles municipal court decisions have denied enforcement of race restrictive covenants. ${ }^{118}$ There is thus some judicial authority that the non-discrimination conception embodied in the Fourteenth Amendment is broad enough to include restrictive covenants within its purview.

Doctrinally, to bring the broad prohibitions of the Fifth and Fourteenth Amendments into play in a specific case, it must be shown that judicial enforcement or restrictive covenants involves action which is both discriminatory and public. ${ }^{119}$ Some courts have denied that enforcement of covenants is discriminatory on the ground that any group may invoke judicial aid in enforcing covenants. ${ }^{120}$ However, in the light of the sociological data already

116. Besides the violation of the Amendment, Judge Ross cited public policy, and a treaty with China, which granted its nationals in this country the same right as those of citizens of the most favored nation, as grounds for refusing to enforce a covenant against Chinese. Id. at 182-3. For a brief discussion of the legal argument against covenants which may be based on the treaty ground, see note 136 infra.

117. "It would be a very narrow construction of the constitutional amendment in question and of the decisions based upon it, and a very restricted application of the broad principles upon which both the amendment and the decisions proceed, to hold that, while states and municipal legislatures are forbidden to discriminate against the Chinese in their legislation, a citizen of the state may lawfully do so by contract, which the courts may enforce." Id. at 182.

118. Anderson v. Auseth, Los Angeles Superior Court, No. 48108, Dec. 6, 1945. The second case is reported in Chicago Defender, Nov. 1, 1947, p. 1, col. 8 .

119. The accepted view, requiring the "public" element, appears, in the case of the Fourteenth Amendment, to be based on the word "state" in the Amendment. As for the Fifth Amendment, the only Supreme Court decision squarely holding that the action of private groups and individuals is not included is Corrigan v. Bucliey, 271 U.S. 323 (1926). See note 105 supra.

This requirement of "public" has led to procedural dificulties in suits against indiridual officials of the state and federal government. The doctrine involved requires ". . . the fiction that the suit must be one against an officer as an itsdividual to escape the bar of sovereign immunity." Block, Suits Against Gocermment Officers and lle Socrcign Immunily Doctrine, 59 HaRv. L. REv. 1060, 1079 (1916) (emphasis added). But ". . . the officer in proceeding under such [unconstitutional] enactment comes into conflict with the superior authority of that [Federal] Constitution, and he is in that case stripped of his official or representatize character and subjected in his person to the consequences of his indicidual conduct." Ex Parte Young, 209 U.S. 123, 159-60 (1908) (emphasis added). Although the Constitution does not provide a remedy for the violation by individuals of the rights it protects, such violation may state a cause of action. Bell v. Hood, 327 U.S. 678 (1946) (federal court has jurisdiction in suit grounded on violation of Fourth and Fifth Amendments). Thus, it might be possible to say that covenants are unconstitutional even before application to the courts for their enforcement. This reasoning illustrates the difficulties involved in attempting a rigid "private"-"public" compartementalization.

120. E.g.: "Under similar circumstances the remedy granted here is equally available to all litigants, regardless of race, or color." Ridgeway v. Cockburn, 163 Misc. 511, 515, 
presented, this view "amounts to saying that if Negroes are excluded from decent housing they may retaliate by excluding whites from slums." 121 Since Negroes are specifically named in the typical covenant and therefore excluded solely because of race, it would seem that judicial enforcement of covenants is by any common-sense standard discriminatory. ${ }^{122}$

Assuming that covenants are discriminatory, one must further show that their enforcement by the courts involves public action. Since the judiciary is a co-equal branch of our traditional tri-partite form of government, judicial action would seem to be no less public than that of the legislature or executive. And it is well established that in supervising the procedural conduct of litigation, ${ }^{123}$ interpreting the common law, ${ }^{124}$ and rendering equitable

296 N.Y. Supp. 936, 943 (Sup. Ct. 1937). Obviously, a restrictive covenant against prostitutes may be enforced; "Yet even prostitutes are a class of our citizenry. If one class may by contract be denied the privilege of use and occupancy, why not another? Whito may exclude black. Black may exclude white." Perkins v. Trustees of Monroe Ave. Church, 79 Ohio App. 457, 70 N.E.2d 487, 491 (1946), appeal dismissed, 147 Ohio St. 537, 72 N.E.2d 97 (1947), pet'n for cert. filed, 16 U.S.L. WeEK 3058 (U.S. Aug. 12, 1947). The 'whites would not be complaining if the racial positions were reversed, Parmalee v. Morris, 218 Mich. 625, 631-2, 188 N.W. 330, 332 (1922).

"Race restrictive covenants do not segregate negroes. They segregate whites. These covenants do not connote prejudice. They have been signed by persons in industrial and professional life whose activities provide employment for thousands of negroes." Curcago Federation of Neigeborhood Associations, Restrictive Covenants 3 (1944).

121. Dissent of Edgerton, J., in Hurd v. Hodge, 162 F.2d at 239 (App. D.C. 1947).

122. The extent to which courts shut their eyes to actual discrimination is illustrated by Mays v. Burgess, 152 F.2d 123 (App. D.C. 1945), involving contempt proceedings against a Negro woman who had not moved out in accordance with the court's decree in Mays $v$. Burgess, 147 F.2d 869 (App. D.C. 1945), cerl. denied, 325 U.S. 868 (1945). It was proved that she and her realty agents had made every effort to find another place for her family to live, but to no avail in the war-time District of Columbia housing shortage. In disregarding this showing, and continuing the racial covenants here covering 1000 properties, the decision suggests the close analogy between judicial and legislative action. "May the validity of a racial covenant be frozen, by judicial action, for the duration of a covenant? The ruling imposes a novel restraint upon the expansion of Negro and mixed areas, makes the acute shortage of Negro housing a little more acute and substantially benefits no one." Edgerton, J., dissenting, $152 \mathrm{~F} .2 \mathrm{~d}$ at $125,126$.

123. Patton v. Mississippi, 68 Sup. Ct. 184 (1947), and cases there cited in footnote 3, dating back to 1879, involve exclusion of Negroes from juries. Examples of other cases in which state court convictions have been reversed are: De Meerleer v. Michigan, 329 U.S. 663 (1947) and Powell v. Alabama, 287 U.S. 45 (1932) (denial of right to counsel); Haley v. Ohio, 16 U.S.L. WeEK 4081 (U.S. Jan. 12, 1948) and Brown v. Mississippi, 297 U.S, 278 (1936) (confession wrongfully obtained); Moore v. Dempsey, 261 U.S. 86 (1923) (mobdominated trial).

Foster v. Illinois, 67 Sup. Ct. 1716 (1947), Adamson v. California, 67 Sup. Ct. 1672 (1947), Louisiana ex rel. Francis v. Resweber, 329 U.S. 459 (1947), and Hysler v. Florida, 315 U.S. 411 (1942), where appeals based on the Fourteenth Amendment were rejected, also denote that court procedure is state action.

124. E.g., Craig v. Harney, 67 Sup. Ct. 1249 (1947); Pennekamp v. Florida, 328 U.S. 331 (1946); and Bridges v. California, 314 U.S. 252 (1941), involving common law contempt; Cantwell v. Connecticut, 310 U.S. 296 (1940), common law breach of peace. 
decrees, ${ }^{125}$ the courts are subject to the constitutional interdictions directed towards governmental action in general. ${ }^{150}$ Since in the typical covenant case, the courts are interpreting the common law and rendering equitable decrees, it would seem that their action in such cases is public action and thus within the scope of the Fifth and Fourteenth Amendments.

In Marsh $v$. Alabama, ${ }^{127}$ moreover, the Supreme Court extended previous notions as to what was embraced by the Fourteenth Amendment. In reversing a conviction of a Jehovah's Witness for trespassing in violation of company regulation on the private property of a company town, the Court appears to have held either the conviction by the state court, or the regulation of the company, to be "public" action within the meaning of the Constitution. ${ }^{128}$ If the former was the ground, an analogy to the covenant situation is suggested. It would seem that a state court decree enforcing a discriminatory covenant is as much "state" action as a state court decree which deprives one Jehovah's Witness of her religious freedom. If the company regulation was the ground on which the Fourteenth Amendment was applied, a further argument is suggested. In developing its position that the actions of a company town were circumscribed by the Fourteenth Amendment, the Court suggested by way of dictum that private land owners together could not so group their property rights as to take action contrary to the Fourteenth Amendment. ${ }^{129}$ In many residential real estate subdivi-

125. E.g., Cafeteria Employees Union v. Angelos, 320 U.S. 293 (1943); Balkery \& Pastry Drivers Local v. Wohl, 315 U.S. 769 (1942); American Federstion of Labor v. Swing, 312 U.S. 321 (1941); and Mill Wagon Drivers Union v. Meadowmoor Dairies, 312 U.S. 237 (1941) involving injunctions against labor union picketing.

126. Typical statements are: "It is doubtless true that a State may act through different agencies, -either by its legislative, its executive, or its judicial authorities; and the prohibitions of the [fourteenth] amendment extend to all action of the State denying equal protection of the laws, whether it be action by one of these agencies or by another." Virginia v. Rives, 100 U.S. 313, 318 (1879).

"If the result above stated were attained by an exercise of the State's legislative power, the transgression of the due process clause of the Fourteenth Amendment would be obvious. . . . The violation is none the less clear when that result is accomplished by the state judiciary in the course of construing an otherwise valid . . . state statute. The federal guaranty of due process extends to state action through its judicial as well as through its legislative, executive or administrative branch of government." Brinkerhoff-Faris Co. v. Hill, 281 U.S. 673, 679-80 (1930).

127. 326 U.S. 501 (1946), 14 MIrck. L. Rev. 848 (1946). See Teft, Afarsh v. Alabama: A Suggestion Concerning Racial Restriclize Cocenants, 4 NAT. BAR. J. 133 (1946).

128. E.g., "The managers appointed by the corporation cannol curtail the liberty of press and religion ... consistently with the purposes of the Constitutional guarantees, and a state statute . . . which enforces such action . . . clearly violates the First and Fourteenth Amendments. . . . That the property rights to the premises where the deprivation of liberty, here involved, took place, were held by others than the public, is not sufficient to justify the State's permitting a corporation lo govern a communily of citizens co as to restrict their fundamental liberties and the enforcement of such restraint by the application of a state statute." Marsh v. Alabama, 326 U.S. 501, 508-9 (1946) (emphasis added).

129. "From these decisions it is clear that had the people of Chicasaw owned all the homes, and all the stores, and all the streets, and all the sidewalks, all those owners tozether 
sions, streets are platted, sewers and water mains laid out and the entire area developed by private subdividers in a manner similar to that of a municipal government. Where restrictive covenants cover such subdivisions ${ }^{130}$ it would seem that they might be considered subject to the interdictions of the Fourteenth Amendment as visualized in the Marsh case dictum.

Moreover, since restrictive covenants typically cover entire residential areas, as appears the fact in all of the cases now pending before the Supreme Court, ${ }^{131}$ their effect is functionally equivalent to that of a racial zoning ordinance. Where covenants do not presently cover entire areas, experience shows that, if encouraged by court enforcement, covenants do in time cover all of the area available for desirable residences. ${ }^{132}$ Thus, in enforcing restrictive covenants, the courts are in effect doing what the legislature was specifically forbidden to do in Buchanan v. Warley. Restrictive covenants, furthermore, may actually be less flexible than zoning ordinances. While under the ordinance in Harmon $v$. Tyler a majority of landowners could have permitted sales to Negroes, in at least one recent covenant case a majority of the original signatories found themselves unable to avoid the covenant and permit sales to Negroes a few years after it was drawn up. ${ }^{133}$ In judicial weighing of ordinances and covenants, similarity of result should call for similarity of judicial treatment.

It is sometimes argued that similarity of result is not a valid criterion, since ordinances involve segregation by direct state action whereas state courts in enforcing restrictive covenants are primarily implementing private agreements and only indirectly aiding segregation. ${ }^{134}$ However, a similar

could not have set up a municipal government with sufficient power to pass an ordinance completely barring the distribution of religious literature." Id. at 505.

130. See note 22 supra.

131. Hurd v. Hodge, 162 F.2d 233 (App. D.C. 1947), cert. granted, 68 Sup. Ct. 100 (1947); Sipes v. McGhee, 316 Mich. 614, 25 N.W.2d 638 (1947), cert. granted, 67 Sup. Ct. 1754 (1947); Kraemer v. Shelley, 198 S.W.2d 679 (Mo. 1946), cert. granted, 67 Sup. Ct. 1751 (1947). As to the District of Columbia background for the Hurd case, consider: "The chicf weapon in the effort to keep Negroes from moving out of overcrowded quarters into white neighborhoods is the restrictive covenant. New building sites and many other areas are now covenanted. ... Even where covenants do not prevail, the powerful local real estate fraternity protects white areas from 'invasion.' The all-white Washington Real Estate Board has a 'code of ethics' which prohibits its members from selling land in predominantly white areas to Negroes, and the realtors are supported in this practice by non-member dealers, banks, and loan companies." CIv. Rrs. REP. 91-2. In Detroit, the city involved in the Sipes case, $80 \%$ of residential areas, excluding those old and settled, is covered by restrictive covenants. Black, Patterns of Restrictive Covenants (unpublished thesis, Wayne University, 1948). For the background of the Shelley case, see Note, 3 NAT. BAR J. 50 (1945).

132. That judges should rule on the basis of such experience was well expressed by Justice Jackson in a recent patent case. ". . . It is immaterial that the tendency is a creeping one rather than one that proceeds at full gallop; nor does the law await arrival at the goal before condemning the direction of the movement." Int'1 Salt Co. v. U. S., 68 Sup. Ct. 12,15 (1947).

133. Schwartz v. Hubbard, 177 P.2d 117 (Okla. 1947) (three years).

134. "But the judiciary does not violate this provision of the federal Constitution merely 
argument that racial zoning ordinances were primarily a valid evercise of the police power or in aid of some lawful public policy and only secondarily effectuating segregation was rejected by the Supreme Court in the ordinance cases. ${ }^{135}$ In Harmon 0 . Tyler, it was contended that since a majority of landowners could permit sales to Negroes the ordinance was primarily in aid of private agreement. This was considered too flimsy an argument to warrant consideration.

An additional argument against race covenant enforcement is our international commitment under the United Nations Charter. ${ }^{15 s}$ The Charter binds its signatories to grant full rights to all individuals regardless of race. ${ }^{137}$ In Re Drummond Wren, ${ }^{13 s}$ the High Court of Ontario found a public policy against racial discrimination in the United Nations Charter sufficient to grant a petition to set aside a covenant against "Jews or persons of objectionable nationality." 139 "If the common law of treason encompasses the stirring up of hatred between different classes of His Majesty's subjects, the common law of public policy is surely adequate to void the restrictive cov-

because it sanctions discriminations that are the outgrowth of contracts made by individuals." Title Guarantee \& Trust Co. v. Garrott, 42 Cal. App. 152, 154, 183 Pac. 470, 471 (1919). "In this appeal we are obliged to differentiate between public rights and private or contractual rights. The former is unquestionably the responsibility of the State, but the action of a State court in requiring or refusing enforcement of private contractual rights is, in our opinion, not within the prohibitions of the 14th Amendment." Sipes v. McGhee, 316 Mich. 614, 25 N.W.2d 638, 645 (1947), cert. granted, 67 Sup. Ct. 1754 (1947). These are typical judicial statements. See Comment, 45 MIrce. L. Rev. 733, 740-2 (1947).

135. See pp. 434-6 supra. The Deans case was cited recently for the proposition urged in the text: "The effect of racial discrimination is not avoided by basing it ostensiby on some other factor. . . . So here discrimination against Negro employees cannot be sustained merely because it purports to be based on promotability, which is itself based on race." Brotherhood of Locomotive Firemen v. Tunstall, 163 F.2d 289, 293 (C.C.A. 4th 1947), cert. denied, 16 U.S.L.WEek 3191 (U.S. Dec. 15, 1947).

136. The U. N. Charter has been duly ratified, 59 Srar. 1031 (1945), and thus has the status of a treaty which is ". . . by the Constitution of the United States, the supreme law, and binding not only upon the government, but upon every citizen. No contract could lawfully be made in violation of their provisions." Kennett v. Chambers, 14 How. 38, 40 (U.S. 1852). Gandolfo v. Hartman, 49 Fed. 181 (S.D. Cal. 1892), is precedent for voiding race covenants as violative of treaty obligations. A segregation ordinance has also been declared indefensible as contrary to treaty commitments. In re Lee Sing, 43 Fed. 359 (N.D. Cal. 1890). But see Note, 13 U. of ChI. L. REv. 477, 481 (1946).

137. Charter of the UNITEd Nations, Art. 55(c) provides: ". . . the United Nations shall promote: . . . universal respect for, and observance of, human rights and fundamental freedoms for all without distinction as to race, sex, language or religion." In Art. 56, "All Members pledge themselves to take joint and separate action in co-operation with the Organization for the achievement of the purposes set forth in Article 55." Language almost identical with Art. 55(c) appears in the Preamble; Art. 1(3) (purposes); Art. 13(1)(b)(duties of General Assembly); Art. 62(2)(duties of Economic and Social Council); and Art. 76(c) (trusteeship system).

138. [1945] 4 D.L.R. 674 (Ont. H. Ct.).

139. The court also cited statements by Roosevelt, Churchill, de Gaulle, and the World Trade Union Congress, as well as the Soviet Constitution, Act of Chapultepec and the Atlantic Charter. Id. at 677, 679-81. 
enant which is here attacked. . . . [N]othing could be more calculated [than restrictive covenants] to create or deepen divisions between existing religious and ethnic groups." 140 There are obvious inconsistencies in a nation's binding itself to the United Nations Charter while at the same time lending its aid to the enforcement of racial covenants.

The constitutionality of the enforcement of restrictive covenants is still an open issue, but a realistic appraisal of their court-aided effect indicates that their enforcement is prohibited by the Fifth and Fourteenth Amendments. ${ }^{141}$ As was said by the court in Gandolfo v. Hartman, "Any result inhibited by the constitution can no more be accomplished by contract of individual citizens than by legislation, and the courts should no more enforce the one than the other. This would seem to be very clear." 142

\section{CONCLUSION}

Although there is no easy or automatic solution to the problem of what is "public" and what is "private" discriminatory action, ${ }^{143}$ it would seem that

140. Id. at 679,678 .

141. The generality of this view is indicated by the number of amicus briefs filed against covenant enforcement in the current Supreme Court litigation: E.g., the Department of Justice, N.Y. Times, Dec. 6, 1947, p. 10, col. 8; the A.F.L. and C.I.O., N.Y. Times, Dec. 5, 1947, p. 16, col. 2; the American Association for the United Nations, N.Y. Times, Dec. 5, 1947, p. 1, col. 2; various Jewish organizations, N.Y. Times, Dec. 2, 1947, p. 26, col. 4.

For appraisals of the "public policy" attack on restrictive covenants, see Nassau, Racial Restrictions on the Alienation and Use of Land, 21 CoNs. B. J. 123, 134-5 (1947); Note, Anti-Discrimination Legislation and International Declarations as Evidence of Public Policy Against Racial Restrictive Covenants, 13 U. of CHI. L. Rev. 477 (1946). Sipes v. McGhee, 316 Mich. 614, 25 N.W.2d 638 (1947), cert. granted, 67 Sup. Ct. 1754 (1947) and Kemp v. Rubin, 188 N.Y. Misc. 310, 69 N.Y.S.2d 680 (Sup. Ct. 1947) are recent judicial refusals to infer a public policy against restrictive covenants from statutes banning discrimination in other fields.

For discussion of the social considerations which should be weighed in a covenant case, see Kahen, Validity of Anti-Negro Restrictive Covenants: A Reconsidcration of the Problem, 12 U. OF CEr. L. REv. 198 (1945). Increasing judicial awareness of these considerations is reflected in the dissents of Edgerton, J., in Hurd v. Hodge, 162 F.2d 233, 235 (App. D.C. 1947), cert. granted, 68 Sup. Ct. 100 (1947), and Mays v. Burgess, 147 F.2d 869, 872 (App. D.C. 1945), cert. denied, 325 U.S. 868 (1945); and the concurring opinion of Traynor, J., in Fairchild v. Raines, 24 Cal.2d 818, 831, 834, 835, 151 P.2d 260, 267, 269 (1944): "Race restriction agreements, undertaking to do what the state cannot, must yield to the public interest in the sound development of the whole community. . . . It is also necessary to determine whether maintenance of this barrier would deprive the colored population of any feasible access to additional housing and compress it within the inflexible boundaries of its present district at the risk of a congestion whose evils would inevitably burst the bounds of that district."

142. 49 Fed. at 182 (1892).

143. At one extreme of the "public"- "private" spectrum is action by public officials, clearly subject to constitutional standards. If this proposition were more widely appreciated, there would apparently be many seemingly sure-fire suits. Besides public housing, see notes 44, 49 supra, there is, for example, the unlitigated policy of exclusion of Negroes enforced by the Alabama Medical Association, which is designated officially as the instrumentality for 
the Stuyvesant Town and state restrictive covenant cases involve what any pragmatic view must recognize as public discriminatory action within the meaning of the constitutional proscription. In both cases, the participation by public officials in the discrimination is substantial, and the social interest in promoting non-discriminatory patterns appears to outweigh the considerations supporting the individual contractual freedom to segregate, relied on by Metropolitan Life and the restrictive covenantors. ${ }^{144}$ The increasingly pluralistic nature of our democratic society suggests that individual civil rights today depend in many instances on the policies of groups that would traditionally have been considered private. If the Fifth and Fourteenth Amendments are to continue to serve a significant protective function, it would seem that their scope must be enlarged to encompass the activities of modern political and economic institutions.

The forthcoming clarification by the Supreme Court of the criteria applicable to cases involving discrimination in housing will inevitably affect the pattern of future American living. Should the Court declare that race covenants may not be enforced, substantial changes in race-residential boundaries would seem an inevitable result. Furthermore, the rationale would pre-

selecting public health officers, ALA. CoDE, tit. 22, $\$ 1$ (1940). "It thus appears that the State Association, and the County Societies . . . are impressed with public functions and are in effect the representative guardians of the public health . . . of the State." Wallier v. Medical Society, 247 Ala. 169, 172, 22 So.2d 715, 717 (19.45). Despite its status of statutory instrumentality the Alabama Medical Association refuses membership to Negro doctors and also effectively excludes them from hospital practice. See CoBb, MEDical CARE AND tHE Plight of the Negro 32-3 (1947).

It is to be noted that action by public officials may vary from close regulation as instanced by a public utility, to the discretionary revoling or granting of licenses and corporate charters. The argument that corporations receive sufficient state support to come within constitutional standards was considered and rejected by the court in a recent covenant case, Northwest Civic Ass'n v. Sheldon, 317 Mfich. 416, 27 N.W.2d 36 (1947), the court recognizing no differences between individual and corporation; but see Berea College v. Kentucky, 211 U.S. 45 (1908) for the suggestion that a state may enforce, in the field of race segregation, a policy for corporations different from that for individuals.

At the other extreme of the spectrum is action not in fact involving any participation by public officials, e.g., the choice of dinner guests. Any uninvited guest-a trespasser-is subject to police and court action. Such state action, presumably applied 10 all equally zrillows regard to color, creed or nationality, is not within the scope of this discussion. But what if the owner attests that he objects only to Negro trespassers? Can the state properly protect this selective use of property?

144. Such balancing of the public interest against the rights of private individuals seems to have been an important factor in the Supreme Court's decision in Miarsh v. Alabama, 320 U. S. 501 (1916). "The State urges in effect that the corporation's right to control the inhabitants of Chickasaw is coextensive with the right of a homeowner to regulate the conduct of his guests. We cannot accept that contention. Ownership does not always mean absolute dominion. . . . When we balance the Constitutional rights of owners of property against those of the people to enjoy freedom of press and religion, as we must here . . . [ve conclude that these property rights do not] justify the State's permitting a corporation to govern a community of citizens so as to restrict their fundamental liberties and the enforcement of such restraint by the application of a state statute." Id. at 505-6, 509. 
sumably doom discrimination in such projects as Stuyvesant Town. Such substantial results would encourage those who see in the law an effective method of eliminating discrimination from American life. "The pervasive gap between our aims and what we actually do is creating a kind of moral dry rot which eats away at the emotional and rational bases of democratic beliefs." ${ }^{145}$ This moral decay has on the whole been aided by the law of discrimination in housing. The forthcoming Court decisions may well proclaim the law an effective instrument to close the gap between existing American race practice and professed democratic theory.

ISAAC N. GRONER $\dagger$

DAVID M. HELFELD $\dagger$

145. Crv. RTs. Rep. 139.

$\dagger$ Member third year class, Yale School of Law. 